\title{
Surface-active cobalt cage complexes: synthesis, surface chemistry, biological activity, and redox properties
}

\author{
Glen W. Walker, ${ }^{* a}$ Rodney J. Geue, ${ }^{a}$ Alan M. Sargeson *a and Carolyn A. Behm ${ }^{b}$ \\ ${ }^{a}$ Research School of Chemistry, The Australian National University, Canberra, ACT, 0200, \\ Australia \\ ${ }^{b}$ School of Biochemistry and Molecular Biology, Faculty of Science, \\ The Australian National University, Canberra, ACT, 0200, Australia
}

Received 26th February 2003, Accepted 4th June 2003

First published as an Advance Article on the web 25th June 2003

\begin{abstract}
Amphiphilic cobalt(III) cage complexes with bridgehead octyl, dodecyl and hexadecyl hydrocarbon chain substituents have been synthesized simply by co-condensation of formaldehyde and long chain aliphatic aldehydes with the tripodal cobalt(III) hexaamine complex, $[\mathrm{Co}(\operatorname{sen})]^{3+}\left\{\operatorname{sen}=4,4^{\prime}, 4^{\prime \prime}\right.$-ethylidynetris(3-azabutan-1-amine) $\}$. The synthetic methodology was also used to prepare a novel chiral surfactant by capping the $\Lambda-(-)_{\mathrm{D}^{-}}[\mathrm{Co}(\mathrm{sen})]^{3+}$ stereoisomer. The cobalt(III) cage complexes with octyl to hexadecyl substituents are all surface active and reduce the surface tension of water to levels approaching those of organic solvents. The dodecyl substituted cage complex forms aggregates in aqueous solution with a critical micelle concentration of $(1.3 \pm 0.1) \times 10^{-3} \mathrm{~mol} \mathrm{dm}^{-3}$ at $25.00^{\circ} \mathrm{C}$. The surfactant cage complexes are biologically active and are lethal at millimolar levels to the tapeworm Hymenolepis diminuta, and the parasitic eukaryote, Tritrichomonas foetus, in vitro. The biological activity of these surfactants appears to involve insertion of the paraffin tail into the organism's exterior membrane and consequent incorporation of the highly charged head-group, which perturbs the normal membrane potential and leads to disintegration of the membrane and death of the organism. The cobalt(III) cage head-group of these surfactants also undergoes a chemically reversible one-electron reduction to the corresponding cobalt(II) cage complex and the construction of oriented films of such redox reagents should be feasible. The reduction potential of the cobalt(III)/(II) couple is shifted from -0.72 to $-0.61 \mathrm{~V}(v s$. saturated calomel electrode) by replacing a bridgehead hydrocarbon chain substituent with an alkoxy substituent. The shift in potential correlates with the electrochemical polar substituent constants of alkyl versus alkoxy chains.
\end{abstract}

\section{Introduction}

Recently, syntheses and properties of a series of amphiphilic derivatives of the cobalt(III) cage complex 1 (Scheme 1) have been reported. ${ }^{1}$ These derivatives included complexes with straight and bifurcated chain substituents such as $\mathbf{2}$ and $\mathbf{3}$, which were good surfactants in aqueous solution. ${ }^{1}$ Such cationic surfactants are unusual because the polar head-group is large ( $10 \AA$ in diameter), highly charged $(3+, 4+$ or $5+)$, redoxactive (cobalt(III)/(II)), and chiral. They are therefore expected to have some novel properties relative to the usual organic surfactants. The biological activity of such surface-active cage complexes is also of interest, since some have been found to be lethal to a range of parasitic worms both in vitro and in vivo. ${ }^{1}$ The amphiphilic complexes are also interesting for applications in surface chemistry, particularly as a class of redox-active surfactant. This expectation is based on the cage complex headgroup which provides an outer-sphere one-electron redox couple ${ }^{2,3}$ that is chemically reversible and tunable. ${ }^{4}$ The generally interesting potential of the cage surfactants in surface chemistry, the significant biological activity of these complexes, and the development of new simple synthetic methodologies

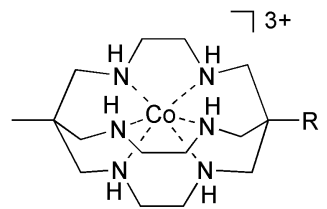

$1 \mathrm{R}=\mathrm{NH}_{2}$

$2 \mathrm{R}=\mathrm{O}\left(\mathrm{CH}_{2}\right)_{9} \mathrm{CH}_{3}$

$\left.3 \mathrm{R}=\mathrm{NH}\left(\mathrm{CH}_{2}\right)_{2} \mathrm{~N}\left(\left(\mathrm{CH}_{2}\right)_{7} \mathrm{CH}_{3}\right)\right)_{2}$

Scheme 1 have together prompted a new study of this class of cage complex.

The first series of amphiphilic cobalt cage complexes was synthesized by coupling the hydrophobic units to the bridgehead amine substituent of cage complex 1 using diazotization or reductive alkylation methods. ${ }^{1}$ However advances in the template synthesis of cage ligands have now made it possible to incorporate the organic substituents directly into the bridgehead ring-system of the cage during the encapsulation process. $^{5-8}$ Therefore, a new and more direct route to even more stable surface-active cobalt cage complexes based on this template synthesis approach has now been developed. The surface chemistry, chiroptical properties, biological activity and electrochemistry of these new complexes have also been investigated.

\section{Results}

Synthesis

A series of imine macrobicyclic cobalt(III) complexes with bridgehead n-octyl $\left(\mathrm{C}_{8}\right)$, n-dodecyl $\left(\mathrm{C}_{12}\right)$ and n-hexadecyl $\left(\mathrm{C}_{16}\right)$ hydrocarbon chain substituents have been synthesized. ${ }^{9}$ They were obtained by the template condensation of appropriate long-chain aliphatic aldehydes and formaldehyde (derived from the solid polymer, paraformaldehyde) with the tripodal cobalt(III) hexaamine precursor, ( \pm )- $[\mathrm{Co}(\operatorname{sen})]^{3+} \mathbf{4}\left\{\operatorname{sen}=4,4^{\prime}, 4^{\prime \prime}-\right.$ ethylidynetris(3-azabutan-1-amine) $\}$, in acetonitrile (Scheme 2). The template reaction, catalyzed by the addition of triethylamine, was complete after a few hours at $\sim 20{ }^{\circ} \mathrm{C}$ and the unsaturated, lipophilic cage ligand products were separated from by-products by chromatography on silica gel. The endocyclic imine functions in these complexes were reduced rapidly and quantitatively by $\mathrm{BH}_{4}{ }^{-}$to give the respective fully saturated hexa-aza cage-ligand complexes 5-7. They were also purified by 

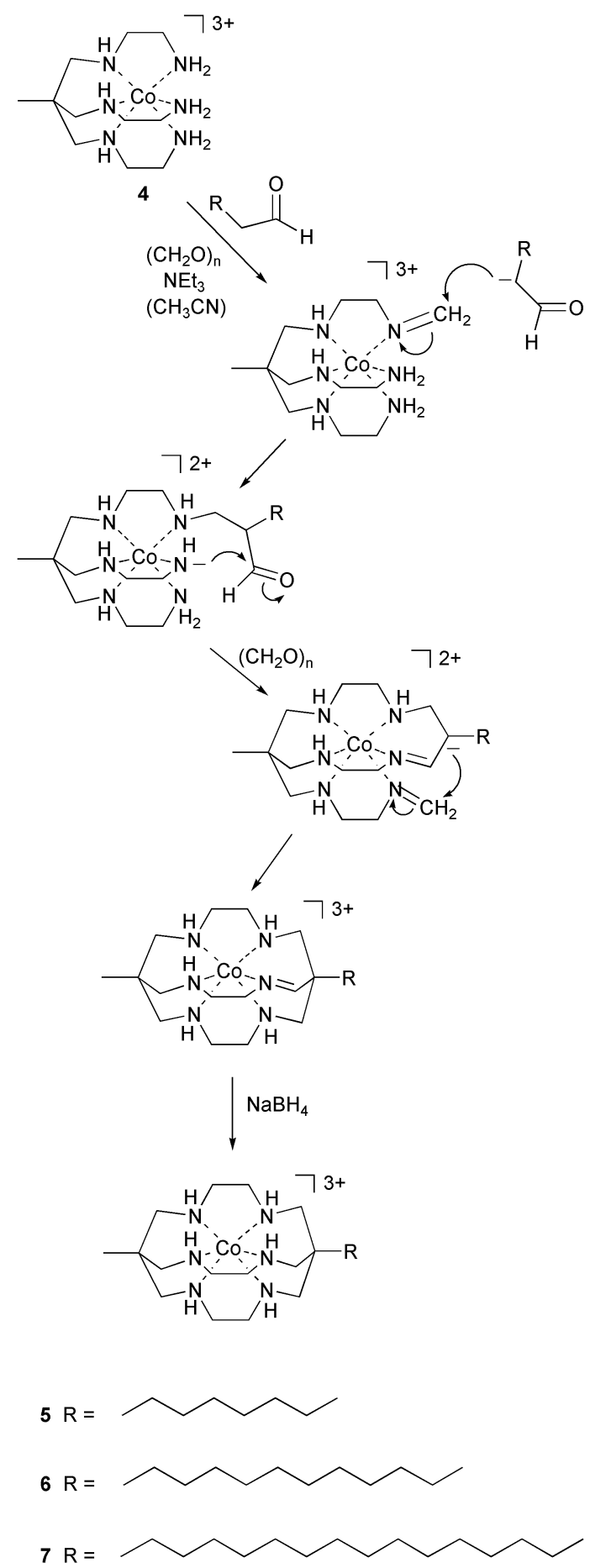

Scheme 2

chromatography on silica gel or by recrystallization from aqueous hydrochloric acid solution. The final yield of cage complexes was in the range $46-58 \%$ based on the mass of precursor complex used in the initial encapsulation reactions.

A chiral dodecyl-substituted cage complex 6 was also synthesized from the optically pure precursor, $\Lambda-(-)_{\mathrm{D}}-[\mathrm{Co}(\mathrm{sen})]^{3+}$. The product cage complex had substantial optical activity, which indicated that the configuration of the precursor complex was largely retained. The optical purity of the product chiral cage complex was gauged from the results of a mode reaction involving condensation of propanal and formaldehyde with $\Lambda-[\mathrm{Co}(\mathrm{sen})]^{3+}$ to give the methyl-substituted analogue of 6, $(-)_{\mathrm{D}}-\left[\mathrm{Co}\left(\left(\mathrm{CH}_{3}\right)_{2}\right.\right.$-sar $\left.)\right] \mathrm{Cl}_{3} 8\left\{\left(\mathrm{CH}_{3}\right)_{2}\right.$-sar = 1,8-dimethyl-3,6, 10,13,16,19-hexaazabicyclo[6.6.6]icosane\}, after reduction. The optical purity of the $(-)_{\mathrm{D}}-\left[\mathrm{Co}\left(\left(\mathrm{CH}_{3}\right)_{2}\right.\right.$ - $\left.\left.\mathrm{Sar}\right)\right] \mathrm{Cl}_{3}$ complex prepared by this route was established by comparison with the enantiomerically pure complex isolated after separation of the racemate on Sephadex cation-exchange resin using an eluent containing $\mathrm{Na}_{2}\left[\mathrm{Sb}_{2}\left((+)_{\mathrm{D}} \text {-tartrato }\right)_{2}\right]$. A comparison of the activities of the chiral cage complexes obtained by the two routes indicated that the template synthesized isomer, $\Lambda-(-)_{D^{-}}$ $\left[\mathrm{Co}\left(\left(\mathrm{CH}_{3}\right)_{2} \text {-sar }\right)\right]^{3+}$, was in $\sim 90 \%$ enantiomeric excess. The low solubility of the surfactant cage complexes in aqueous electrolyte solutions and the difficulty in recrystallizing them precluded a precise analysis of their enantiomeric purity by the chromatographic method but a similar optical purity, at least, is implied by their rotatory strength.

\section{NMR properties}

The imine products from the template reactions were generally reduced in situ on route to the target saturated cage complexes. However, the ${ }^{1} \mathrm{H}$ and ${ }^{13} \mathrm{C}$ NMR spectra of isolated intermediate cobalt(III) mono-imine cage complexes were obtained and they showed characteristic resonances for the endo-cyclic-imine proton $(\delta=8.49-8.55 \mathrm{ppm}$, singlet) and carbon $(\delta=187.4 \mathrm{ppm})$, respectively. The loss of these resonances after treatment of the imine cage complexes with $\mathrm{BH}_{4}^{-}$and the fewer signals in the NMR spectra of the products were consistent with the reduction of the unsaturated ligands to the corresponding $C_{3}$-saturated macrobicycles.

The ${ }^{1} \mathrm{H}$ and ${ }^{13} \mathrm{C}$ NMR spectra of the n-octyl-substituted hexaaza cage complex 5, are given in Fig. 1. In the ${ }^{1} \mathrm{H}$ spectrum of $\mathbf{5}$, the two sets of chemically inequivalent methylene protons on the apical rings of the cage ligand show a single $\mathrm{AB}$ doublet pair ( $J=13.7 \mathrm{~Hz}, 12$ protons) centered at $\delta=2.75 \mathrm{ppm}$. The methylene protons of the $\mathrm{NCH}_{2} \mathrm{CH}_{2} \mathrm{~N}$ moieties give rise to a more complex $\mathrm{AA}^{\prime} \mathrm{BB}^{\prime}$ spin system centered at $\delta=3.0 \mathrm{ppm}$ (12 protons). The methyl group attached directly to the cage bridgehead gives a characteristic singlet at $\delta=0.91 \mathrm{ppm}$ (3 protons), whereas the terminal methyl group of the $\mathrm{C}_{8}$-hydrocarbon chain substituent gives a triplet at $\delta=0.84 \mathrm{ppm}$ ( 3 protons). Multiple overlapping resonances from the methylene protons of the $\mathrm{C}_{8}$-chain gave rise to a broad singlet at $\delta=1.25 \mathrm{ppm}$ (14 protons). The ${ }^{1} \mathrm{H}$ NMR spectra of cage complexes with longer hydrocarbon chain substituents, in $\mathrm{D}_{2} \mathrm{O}$, were essentially identical to that of $\mathbf{5}$, apart from larger methylene envelope signals. An additional broad singlet at $\delta=8.93 \mathrm{ppm}$ in the spectra of complexes, in $\mathrm{CDCl}_{3}$, results from protons attached to the coordinated secondary amine nitrogen atoms of the macrobicyclic cage since these no longer exchange with the solvent.

The ${ }^{13} \mathrm{C}$ NMR spectrum of $\mathbf{5}$ is characterized by resonances due to the methylene carbons $(\delta=23.1-35.2 \mathrm{ppm})$ and the
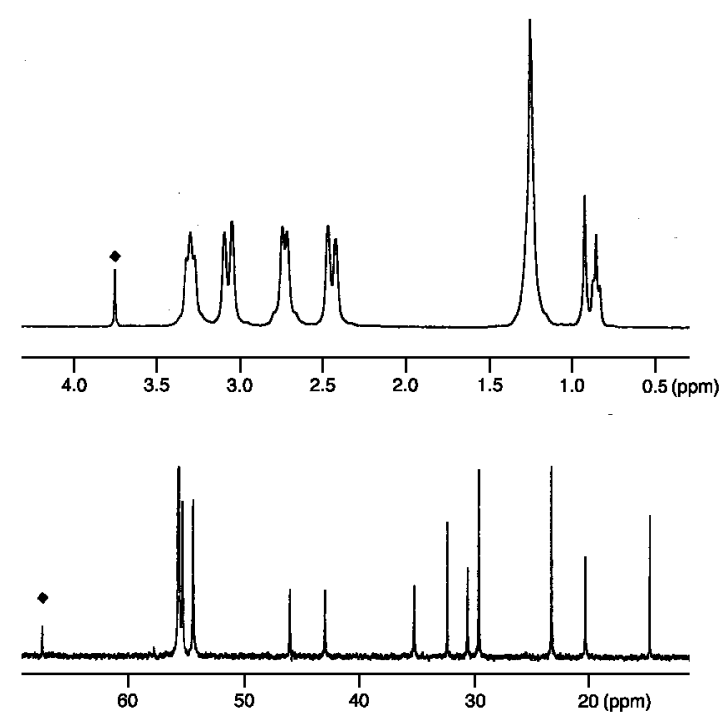

Fig. $1{ }^{1} \mathrm{H}$ NMR spectrum (upper) and broad-band proton-decoupled ${ }^{13} \mathrm{C}$ NMR spectrum (lower) of the cobalt(III) $\mathrm{C}_{8}$-cage complex 5 in $\mathrm{D}_{2} \mathrm{O}$; $\checkmark$ 1,4-dioxane. 
terminal methyl carbon $(\delta=14.6 \mathrm{ppm})$ of the $\mathrm{C}_{8}$-hydrocarbon chain. The effective $C_{3}$-symmetry of complex $\mathbf{5}$ yields two inequivalent quaternary carbon resonances at $\delta=42.9$ and 46.0 ppm, and four inequivalent methylene carbon resonances at $\delta=54.3-55.6 \mathrm{ppm}$. The methyl carbon substituent attached directly to the cage ligand bridgehead displays another characteristic resonance at $\delta=20.2 \mathrm{ppm}$. The ${ }^{13} \mathrm{C}$ NMR spectra of the cage-ligand complexes with longer hydrocarbon-chain substituents are nearly identical to that of $\mathbf{5}$, apart from additional hydrocarbon-chain methylene resonances.

\section{Surface activity}

The surfactant cobalt(III) cage complexes 5-7 displayed excellent wetting properties. Their surface-activity in aqueous solution was readily apparent from the characteristic yellow-orange foam, which formed above a shaken aqueous solution and persisted for several minutes. The amphiphilic complexes also formed aggregates in aqueous solution. This was followed for complex $\mathbf{6}$ by measuring the electrical conductivity of solutions of the tri-chloride salt in $\mathrm{H}_{2} \mathrm{O}$ as a function of complex concentration at $25.00( \pm 0.02){ }^{\circ} \mathrm{C}$. The data reveal a linear concentration dependence for the conductivity over two distinct ranges separated by a weak discontinuity for cation concentrations in the range $(1.25-1.5) \times 10^{-3} \mathrm{~mol} \mathrm{dm}^{-3}$ (Fig. 2). The reduced molar conductivity above the discontinuity is consistent with aggregation of the surfactant. ${ }^{10} \mathrm{~A}$ critical micelle concentration of $(1.3 \pm 0.1) \times 10^{-3} \mathrm{~mol} \mathrm{dm}^{-3}$ was evaluated by extrapolation from a least squares linear regression analysis of the conductivity profile as indicated in Fig. 2. Attempts were made to probe the structure of these aggregates by small angle X-ray scattering, but no scattering attributable to well organized assemblies was detected.

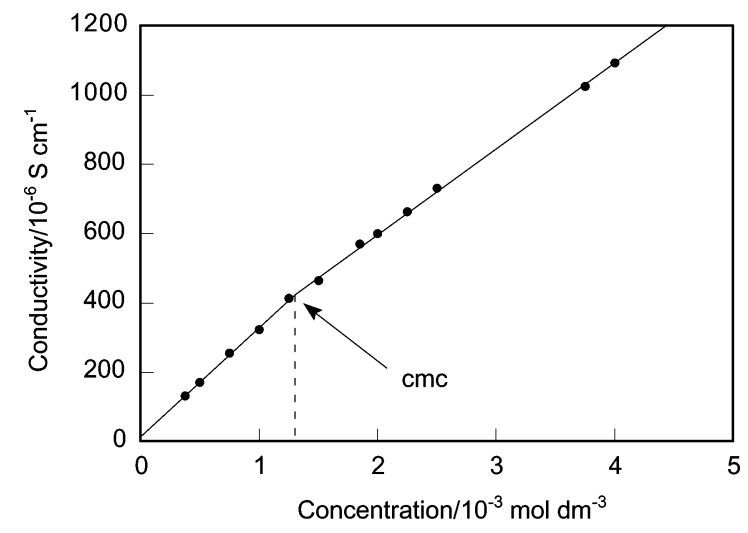

Fig. 2 The concentration dependence of the conductivity of solutions of the cobalt(III) $\mathrm{C}_{12}$-cage complex 6 in $\mathrm{H}_{2} \mathrm{O}$ at $25.00 \pm 0.02{ }^{\circ} \mathrm{C}$.

\section{Chiroptical properties}

The visible absorption, optical rotatory dispersion (ORD), and circular dichroism (CD) spectra of the $\Lambda$ isomer of the $\mathrm{C}_{12^{-}}$ substituted cage complex, $\mathbf{6}$, in aqueous solution are given in Fig. 3. The electronic absorption spectra and the chiroptical properties of this complex are typical of dissymmetric cobalt(III) hexaamine complexes in this series. The visible and near-UV absorption spectrum consists of two nearly symmetric absorption bands centered at 470 and $343 \mathrm{~nm}$, which have their respective origins in the ${ }^{1} \mathrm{~A}_{1 \mathrm{~g}} \longrightarrow{ }^{1} \mathrm{~T}_{1 \mathrm{~g}}$ and ${ }^{1} \mathrm{~A}_{1 \mathrm{~g}} \rightarrow{ }^{1} \mathrm{~T}_{2 \mathrm{~g}}$ electronic transitions of an octahedral $\mathrm{CoN}_{6}$ chromophore. ${ }^{11,12}$ The chiroptical properties are dominated by transitions associated with the lower energy $d-d$ electronic absorption band. Hence, the visible $\mathrm{CD}$ spectrum of the $\Lambda$ isomer of $\mathbf{6}$ is dominated by a nearly symmetrical band with a net negative rotational strength centered at $468 \pm 2 \mathrm{~nm}$ (Fig. 3c). This band can be attributed to the dominance of the negative rotational strength of the ${ }^{1} \mathrm{~A}_{1} \rightarrow$ ${ }^{1} \mathrm{~A}_{2}(-)$ transition over the ${ }^{1} \mathrm{~A}_{1} \longrightarrow{ }^{1} \mathrm{E}_{\mathrm{a}}(+)$ transition by analogy

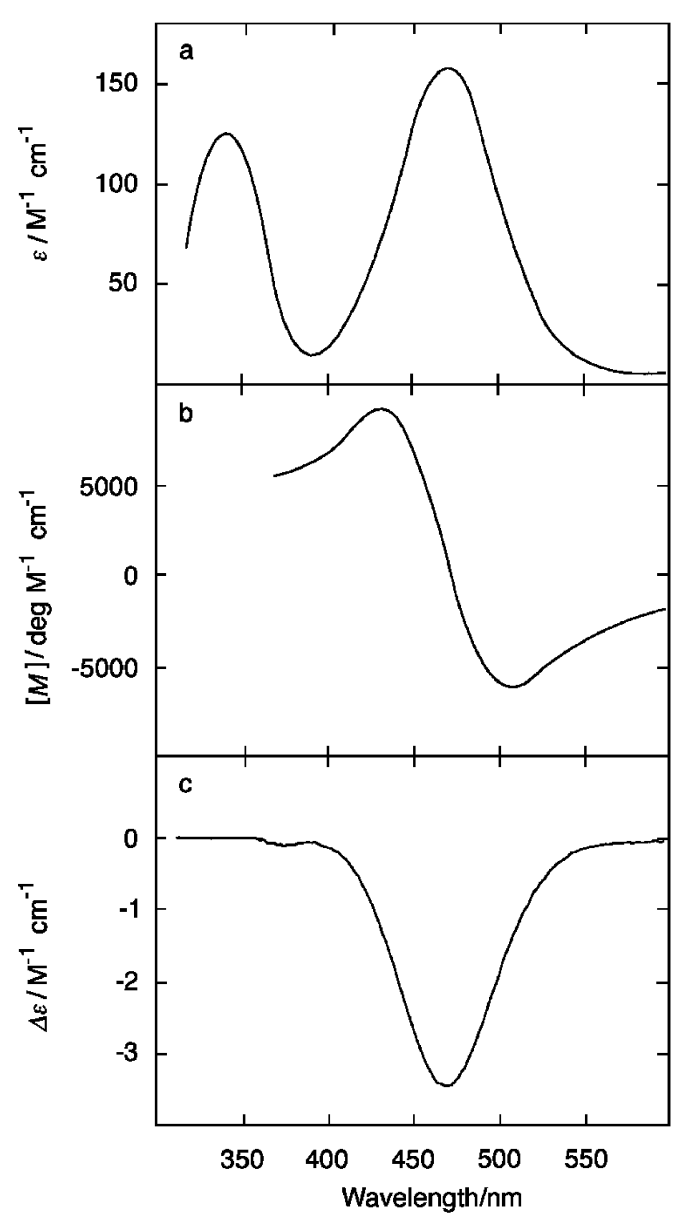

Fig. 3 The visible absorption (a), optical rotatory dispersion (b), and circular dichroism (c) spectra of the $(-)_{\mathrm{D}^{-}}$-isomer of the cobalt(III) $\mathrm{C}_{12^{-}}$ cage complex 6 in $\mathrm{H}_{2} \mathrm{O}$.

with the CD of the structurally related cobalt(III) cage complex, $\Lambda$ - $[\mathrm{Co}(\mathrm{sep})]^{3+}$ (where sep $=1,3,6,8,10,13,16,19$-octaazabicyclo[6.6.6]icosane), provided the chromophore of the chiral surfactant cage complex has an effective $D_{3}$-symmetry. ${ }^{12,13}$ The formation of aggregates of these complexes does not appear to affect their chiroptical properties significantly. Various spectra were recorded at concentrations above and below the critical micelle concentration of $\mathbf{6}$ and no unusual effects were observed.

\section{Biological activity}

The anthelmintic activity of the new cage complex 6 was tested against the cestode, Hymenolepis diminuta, in vitro. The tapeworm was incubated with a $10^{-3} \mathrm{~mol} \mathrm{dm} \mathrm{dm}^{-3}$ solution of 6 in a buffered physiological saline solution and the progress of the treatment was monitored photographically (Fig. 4). After extraction from the rat host, the worm was mobile and in an uncoiled form (plate a). However, within 5-10 minutes of the administration of the surfactant, the parasite had tightly coiled itself and commenced to lose its membranous outer coat (tegument). Death occurred within the next $1.5 \mathrm{~h}$ as evinced by the parasite's complete lack of mobility and further disintegration of the tegument. A magnified view of the worm at this point (plate b) shows more clearly the tightly coiled dead worm and dissociated fragments of the parasite's tegument. The mode of action of $\mathbf{6}$ against Hymenolepis diminuta is similar to the effect of the related surfactant cage complexes $\mathbf{2}$ and $\mathbf{3}$ on this cestode. ${ }^{1}$ Also, such cobalt(III) cage complexes without hydrophobic chain susbtituents have no obvious damaging effects on cestode membranes at millimolar concentrations. ${ }^{1}$

The effect of the new range of surfactant cage complexes on biological membranes was also assessed with sheep erythro- 

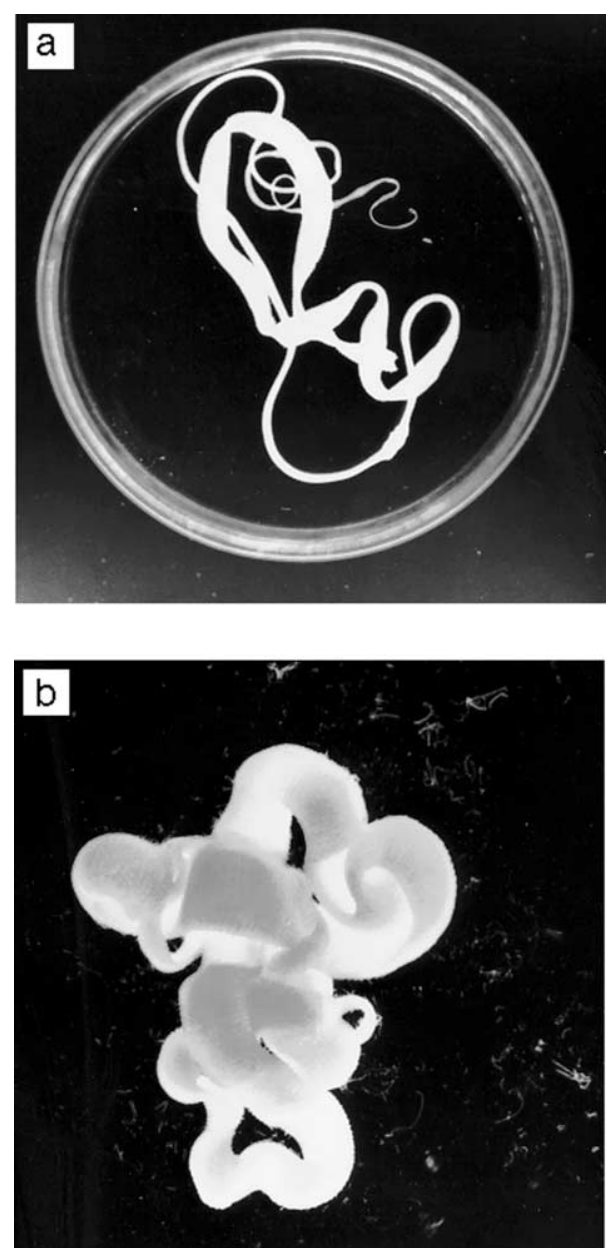

Fig. 4 The effects of the cobalt(III) $\mathrm{C}_{12}$-cage complex $6\left(10^{-3} \mathrm{~mol}\right.$ $\mathrm{dm}^{-3}$ ) on Hymenolepis diminuta in a buffered physiological saline solution at intervals after administration of the surfactant: plate a $(30 \mathrm{~s})$; plate b $(1.5 \mathrm{~h}$, magnified view $(\times 2.5))$.

cytes (red-blood cells) and complex $\mathbf{6}$. A sample of sheep whole blood diluted in saline was treated with concentrations of $\mathbf{6}$ in the range $(0.5-1.6) \times 10^{-4} \mathrm{~mol} \mathrm{dm}^{-3}$. The gross changes in cell morphology were monitored by light microscopy. The erythrocytes appeared to remain intact after treatment with concentrations of complex $\leq 1.0 \times 10^{-4} \mathrm{~mol} \mathrm{dm}^{-3}$ for 5-10 minutes, although, the cells did swell and clump together when treated with even the most dilute solutions of the complex. The first appearance of empty erythrocyte vesicles (ghost cells) was noted for surfactant concentrations between $(1.0-1.1) \times 10^{-4}$ mol dm${ }^{-3}$. For concentrations of complex between $(1.2-1.6) \times$ $10^{-4} \mathrm{~mol} \mathrm{dm}^{-3}$, the visible sample consisted entirely of the products of haemolysis, particularly aggregates of ghost cells Complexes $\mathbf{2}$ and $\mathbf{3}$ have comparable haemolytic activity. ${ }^{1}$

The in vitro activity of the new single chain surfactant complex $\mathbf{6}$ and the bifurcated chain complexes $\mathbf{3}$ was tested against the bovine protozoan parasite, Tritrichomonas foetus ( $T$. foetus). This parasite is a sexually transmitted anaerobic eukaroyte that is capable of causing infertility through infection of the uterus. ${ }^{14}$ The lethal activity of these two complexes against $T$. foetus is summarized in Table 1 . Under the conditions of this experiment, both 3 and $\mathbf{6}$ were lethal within 15 minutes at the highest concentration $\left(10^{-3} \mathrm{~mol} \mathrm{dm}{ }^{-3}\right)$. However, at the lowest concentration of complex $\left(10^{-5} \mathrm{~mol} \mathrm{dm}^{-3}\right)$, the bifurcated chain surfactant 3 was significantly more active.

\section{Electrochemistry}

The redox properties of the surface active cobalt(III) cage complexes 2, 5 and $\mathbf{6}$ in aqueous solution were analyzed by cyclic voltammetry. The cyclic voltammogram of each
Table 1 The time required for various concentrations of surface-active cobalt(III) cage complexes to have a lethal effect on Tritrichomonas foetus parasites in vitro

\begin{tabular}{llc}
\hline & \multicolumn{2}{c}{ Time to parasite death ${ }^{a b} / \mathrm{h}$} \\
\cline { 2 - 3 } Concentration $/ \mathrm{mol} \mathrm{dm}^{-3}$ & Complex 3 & Complex 6 \\
\hline $10^{-5}$ & $0.5-2$ & $\sim 24$ \\
$10^{-4}$ & 0.3 & 0.5 \\
$10^{-3}$ & $<0.2$ & $<0.2$
\end{tabular}

${ }^{a}$ Parasites were incubated in microlitre plates at $37{ }^{\circ} \mathrm{C}$ in a sterile saline solution containing a phosphate buffer $\left(\mathrm{pH} \mathrm{7.2)}\right.$ and $0.05 \mathrm{~mol} \mathrm{dm}^{-3}$ glucose. ${ }^{b}$ The parasites were treated with the surfactants under aerobic conditions; each test was done in duplicate.

surfactant features a single quasi-reversible wave at negative reduction potentials as shown for the $\mathrm{C}_{12}$-cage complex 6 in Fig. 5. The wave is assigned to the chemically reversible reduction of the encapsulated cobalt(III)-ion head-group to the corresponding substitutionally-inert cobalt(II)-cage complex. The measured half-wave potential $\left(E_{1 / 2}\right)$ for the cobalt(III)/(II) couple of each surfactant and other electrochemical parameters are summarized in Table 2. The electrochemistry of the related surface inactive cage complex $\mathbf{8}$ was investigated for comparison and its electrochemical properties are also reported in Table 2. The $\mathrm{C}_{16}$ cage complex 7 was too insoluble in aqueous electrolyte solutions containing chloride ion to be included.

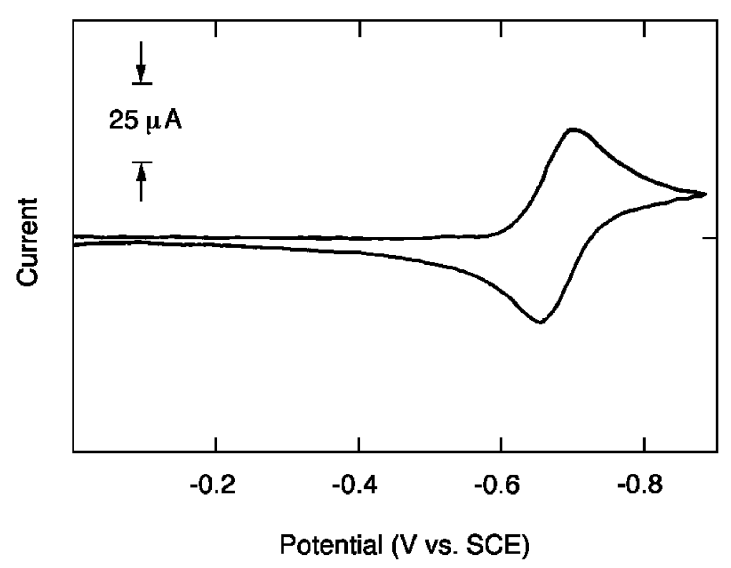

Fig. 5 The cyclic voltammogram of a $5.1 \times 10^{-3} \mathrm{~mol} \mathrm{dm}^{-3}$ solution of the cobalt(III) $\mathrm{C}_{12}$-cage complex 6 in aqueous $0.2 \mathrm{~mol} \mathrm{dm}{ }^{-3} \mathrm{NaCl}$ (scan rate $100 \mathrm{mV} \mathrm{s}^{-1}$; glassy carbon working electrode).

The aqueous electrochemical properties of the surface-active cage complexes are similar to those of the surface-inactive complex 8, apart from some adsorption of the surfactant cage complexes on the working electrode. Adsorption effects were most pronounced for the reduced forms of complexes $\mathbf{2}$ and $\mathbf{6}$. For example, in the cyclic voltammetry of complex $6\left(0.5 \times 10^{-3}\right.$ mol $\mathrm{dm}^{-3}$ ) the anodic wave became increasingly symmetrical with respect to the peak current and the cathodic peak potential shifted anodically by $25 \mathrm{mV}$ as the scan rate was increased from 10 to $1000 \mathrm{mV} \mathrm{s}^{-1}$. The anodic peak potential remained essentially constant over this range of scan rates, thus reducing the peak-to-peak separation $\left(\Delta E_{\mathrm{p}}\right)$ to $27 \mathrm{mV}$ at a scan rate of 1000 $\mathrm{mV} \mathrm{s}^{-1}$. This peak separation is much less than that expected for a fully reversible one-electron reduction controlled by diffusion at the electrode $\left(\Delta E_{\mathrm{p}}=59 \mathrm{mV}\right.$ at $\left.25^{\circ} \mathrm{C}\right)$ and is indicative of adsorption of the reduced product of an electrochemical reaction on the working electrode surface. ${ }^{15}$ The electrochemistry of each complex is relatively less affected by adsorption effects when higher bulk concentrations of the complexes are used, as expected. ${ }^{15}$ Adsorption of cobalt(II) cage complexes from aqueous electrolyte solutions onto working electrodes has been 
Table 2 The half-wave potential, $E_{1 / 2}$, peak-to-peak separation, $\Delta E_{\mathrm{p}}$, and the ratio of anodic peak-current to cathodic peak-current, $i_{\mathrm{p}}{ }^{\mathrm{a}} / i_{\mathrm{p}}{ }^{\mathrm{c}}$, for the cobalt(III)/(II) couple of cage complexes in aqueous $0.2 \mathrm{~mol} \mathrm{dm}^{-3} \mathrm{NaCl}^{a}$

\begin{tabular}{|c|c|c|c|c|c|}
\hline Complex & Substituent & Concentration $/ 10^{-3} \mathrm{~mol} \mathrm{dm}^{-3}$ & $E_{1 / 2}^{b c} / \mathrm{V}$ & $\Delta E_{\mathrm{p}}{ }^{d} / \mathrm{mV}$ & $i_{\mathrm{p}}{ }^{\mathrm{a}} / i_{\mathrm{p}}{ }^{\mathrm{c}}$ \\
\hline 8 & $\mathrm{C}_{1}$ & 1.0 & -0.72 & 73 & 0.7 \\
\hline 5 & $\mathrm{C}_{8}$ & $\begin{array}{l}1.0 \\
7.4\end{array}$ & $\begin{array}{l}-0.72^{e} \\
-0.72\end{array}$ & $\begin{array}{l}65^{f} \\
87\end{array}$ & $\begin{array}{l}0.8^{g} \\
0.8\end{array}$ \\
\hline 6 & $\mathrm{C}_{12}$ & $\begin{array}{l}0.1 \\
0.5 \\
5.1\end{array}$ & $\begin{array}{l}-0.70 \\
-0.69 \\
-0.69\end{array}$ & $\begin{array}{l}31 \\
30 \\
47\end{array}$ & $\begin{array}{l}0.8 \\
1.0 \\
0.9\end{array}$ \\
\hline 2 & $\mathrm{OC}_{10}$ & $\begin{array}{r}1.0 \\
10.0\end{array}$ & $\begin{array}{l}-0.61 \\
-0.61\end{array}$ & $\begin{array}{l}53 \\
58\end{array}$ & $\begin{array}{l}0.9 \\
1.0\end{array}$ \\
\hline
\end{tabular}

${ }^{a}$ Electrochemical conditions: glassy carbon working electrode; saturated calomel reference electrode (SCE); platinum wire auxiliary electrode; scan rate $=100 \mathrm{mV} \mathrm{s}^{-1} ; T=25 \pm 0.2^{\circ} \mathrm{C}^{{ }^{b}} E_{1 / 2}=\left(E_{\mathrm{p}}{ }^{\mathrm{c}}+E_{\mathrm{p}}{ }^{\mathrm{a}}\right) / 2 .{ }^{c} v s$. the SCE. ${ }^{d} \Delta E_{\mathrm{p}}=E_{\mathrm{p}}{ }^{\mathrm{a}}-E_{\mathrm{p}}{ }^{\mathrm{c}} \cdot{ }^{e} E_{1 / 2}=-0.72 \mathrm{~V}((v s$. SCE $)$ gold disk working electrode $)$. ${ }^{f} \Delta E_{\mathrm{p}}=70 \mathrm{mV}$ (gold disk working electrode). ${ }^{g} i_{\mathrm{p}} \mathrm{a} / i_{\mathrm{p}}{ }^{\mathrm{c}}=0.5$ (gold disk working electrode).

noted previously and is not specific to amphiphilic cage complexes. ${ }^{4,16}$

The formal potential for the cobalt(III)/(II) couple of the alkoxy-substituted complex $\mathbf{2}$ is $110 \mathrm{mV}$ more positive than the cobalt(III)/(II) couple for cage complexes with only alkyl substituents, which all have comparable formal potentials. The sensitivity of the metal centered formal potential of the cage complexes to changes in ligand substituent is well established and can be treated quantitatively using a linear free energy relationship. ${ }^{17}$ In this approach, a Hammett $\rho-\sigma$ treatment is applied to equilibria involving the reversible cobalt(III)/(II) couple of substituted sarcophagine cage complexes. For the Hammett relationship, the standard reaction $(\rho=1)$ is defined by eqn. (1). ${ }^{17}$

$$
\begin{aligned}
& {\left[\mathrm{Co}^{\mathrm{II}}(\mathrm{sar})\right]^{2+}+\left[\mathrm{Co}^{\mathrm{III}}((\mathrm{X}, \mathrm{Y})-\mathrm{sar})\right]^{3+} }= \\
& {\left[\mathrm{Co}{ }^{\mathrm{III}}(\mathrm{sar})\right]^{3+}+\left[\mathrm{Co}^{\mathrm{II}}((\mathrm{X}, \mathrm{Y})-\mathrm{sar})\right]^{2+} }
\end{aligned}
$$

where sar $(3,6,10,13,16,19$-hexaazabicyclo[6.6.6]icosane) is the unsubstituted parent ligand of this series of cage complexes and the $[\mathrm{Co}(\mathrm{sar})]^{3+/ 2+}$ couple is the reference redox couple. Deviations in the potential of cobalt(III)/(II) cage couples from the reference couple are correlated with electrochemical polar substituent constants, $\sigma_{\mathrm{E}}$, for substituents $\mathrm{X}$ and $\mathrm{Y}$ in the 1 and 8 bridgehead positions of the macrobicyclic cage ligand, $\sigma_{\mathrm{E}}(\mathrm{X})$ and $\sigma_{\mathrm{E}}(\mathrm{Y})$, respectively. ${ }^{17}$ The sum of the electrochemical inductive substituent effects for substituents $\mathrm{X}$ and $\mathrm{Y}, \sigma_{\mathrm{E}}(\mathrm{X})+$ $\sigma_{\mathrm{E}}(\mathrm{Y})\left(=\sigma_{\mathrm{E}}{ }^{\prime}\right)$, is related to the difference in half-wave potentials $\left(E_{1 / 2}\right)$ for the couples in the standard reaction, $\Delta E_{1 / 2}$, by eqn. (2), for reactions at $25^{\circ} \mathrm{C}$,

$$
\sigma_{\mathrm{E}}{ }^{\prime}=16.9 \Delta E_{1 / 2}
$$

Electrochemical substituent constants have been determined for a variety of bridgehead substituents including methyl groups; $\sigma_{\mathrm{E}}\left(\mathrm{CH}_{3}\right)=-0.18$, where $\sigma_{\mathrm{E}}(\mathrm{H})=0$, by definition. ${ }^{17}$ The electrochemical polar substituent constants for alkyl chains and alkoxy chains were calculated from a related series of inductive substituent constants, $\sigma_{1}$, for ethyl and methoxy substituents, which have been derived by Grob and coworkers from studies of the trend in the $\mathrm{p} K_{\mathrm{a}}$ of 4 -substituted quinuclidinium salts. ${ }^{18}$ A linear relationship exists between the inductive substituent constants, $\sigma_{1}$, and the electrochemical polar substituent constant, $\sigma_{\mathrm{E}}$, for the same substituent attached to the bridgehead of a cobalt sarcophagine complex. ${ }^{17}$ The $\sigma_{1}$ values derived by Grob and coworkers for ethyl and methoxy substituents $(0.02$ and 1.89 , respectively) were taken to approximate the inductive substituent constants for alkyl chains and alkoxy chains, respectively. Electrochemical polar substituent constants for ethyl and methoxy substituents of -0.3 and 1.8 , respectively, were calculated based on the respective values of $\sigma_{1}$. The values of $\Delta E_{1 / 2}$ for the two surfactant cage complexes were calculated from eqn. (2) by substitution of $\sigma_{\mathrm{E}}{ }^{\prime}$ for complexes 5 and $\mathbf{2}(-0.5$ and 1.6, respectively). The expected cobalt(III)/(II) reduction potential for both surfactant cage complexes in $0.2 \mathrm{M} \mathrm{NaCl}$ (at $25^{\circ} \mathrm{C}$ ) was finally obtained by addition of the respective $\Delta E_{1 / 2}$ values to $E_{1 / 2}$ for the reference couple, [Co(sar) $]^{3+/ 2+}$ (measured under the same conditions); $E_{1 / 2}\left([\mathrm{Co}(\mathrm{sar})]^{3+/ 2+}\right)=-0.70 \mathrm{~V}(v$ s. SCE $)$ in $0.2 \mathrm{M} \mathrm{NaCl}$ at $25{ }^{\circ} \mathrm{C}$. Excellent agreement was obtained between calculated and measured half-wave potentials for both redox couples: $E_{1 / 2}{ }^{\text {calc }} \mathbf{5}^{3+/ 2+}=-0.73 \mathrm{~V}$ (vs. SCE) $\left(E_{1 / 2}{ }^{\text {obs }}=\right.$ $-0.72 \mathrm{~V}) ; E_{1 / 2}{ }^{\text {calc }} 2^{3+/ 2+}=-0.61 \mathrm{~V}(v s . \mathrm{SCE})\left(E_{1 / 2}{ }^{\text {obs }}=-0.61 \mathrm{~V}\right)$.

\section{Discussion}

The template synthesis is a relatively efficient and general way of introducing various substituents into the cages of this type. In the present study, long chain aliphatic aldehydes were chosen as capping reagents in order to give cage complexes with very stable chain substituents of sufficient length to bracket the important range for straight chain ionic surfactants in aqueous solution, i.e., $\mathrm{C}_{8}-\mathrm{C}_{16}$. However, the encapsulation chemistry is not limited to these simple straight chain aldehydes or even $\alpha$-methylene aldehydes as capping reagents. Several other studies have demonstrated that a range of weak $\mathrm{CH}$-acids with an amine condensable group and an $\alpha$-methylene or $\alpha$-methyl group can be used to form bridgehead ring systems by this template encapsulation chemistry. ${ }^{7,8}$ These results imply that many other amphiphilic cage cations with varying types of hydrophobic units could be synthesized by this approach. In addition, a variety of closely related tripodal cobalt(III)-amine complexes with similar stereochemistry and reactivity towards encapsulation are known which could be suitable as precursors to surfactant complexes with different cage head-groups. ${ }^{19,20}$ These systems are relevant for synthesizing surfactant complexes with different reduction potentials and electron transfer rate constants, or for modulating the physical dimensions of the head-group. The latter property may be of considerable importance for the surface and biological activity of these surfactants. Even more general routes to surfactant cage complexes could follow from a successful demetallation of the cobalt cage surfactants. ${ }^{21}$

The racemic precursor complex $( \pm)-[\mathrm{Co}(\mathrm{sen})]^{3+}$ used in the encapsulation reactions is a substitutionally inert hexadentate coordination complex that is readily resolved into its constituent enantiomers. It was expected that a template cage synthesis beginning with one of the resolved enantiomers of the precursor would yield a chiral surfactant coordination complex. This expectation was largely realised when the optically pure enantiomer, $\Lambda$ - $[\mathrm{Co}(\mathrm{sen})]^{3+}$, was condensed with tetradecanal and paraformaldehyde to give an optically-active cobalt(III) cage surfactant with an n-dodecyl substituent. An estimate of 
the optical purity of the product complex by comparison with a model reaction indicated that the chiral cage surfactant was obtained in at least $90 \%$ enantiomeric excess. Thus, the template reaction clearly proceeds with substantial retention of the initial configuration of the cobalt(III)-ion, although a limited amount of racemisation can occur under the reaction conditions. This must happen via a trace of intermediate cobalt(II)sen complex because the cage complexes of cobalt(II) are known to be exceptionally slow to racemise. ${ }^{12}$ Optically pure surfactant cage complexes might be attainable by elution from a chiral column in mixed aqueous/non-aqueous solutions but regardless of this possibility, the direct availability of surfaceactive chiral complexes with substantial rotatory power adds a new dimension to probing surface phenomena.

The amphiphilic cobalt cage complexes with $\mathrm{C}_{8}$ or longer hydrocarbon chains synthesized in this and previous studies are all good surfactants. For example, the $\mathrm{C}_{12}$ substituted cage complex 6 reduces the surface tension of water by $c a$. $60 \%$ to $25-30 \mathrm{~mJ} \mathrm{~m}^{-2}$ in $2 \times 10^{-3} \mathrm{~mol} \mathrm{dm}^{-3}$ solutions of the complex at $20{ }^{\circ} \mathrm{C}^{22}$ This value is close to the surface tension of organic solvents and is comparable with the decrease in surface tension obtained with the best traditional ionic surfactants in aqueous solution. ${ }^{23}$ The surface tension and conductimetric studies of surfactant cobalt cage complexes in aqueous solution also indicate some aggregation of the cations at millimolar concentrations. However, the nature of these aggregates is as yet unclear. As previously noted, the cobalt(III) cage head-group of these surfactants is slightly ellipsoidal with a diameter of $\sim 10 \AA$ and $40-50$ of these cations could be assembled to form a spherical micelle with a radius of $\sim 24 \AA^{1} .^{1}$ Attempts have been made to probe the structure of the aggregates by small angle X-ray scattering, but no conclusive results were obtained. By implication they are not well ordered dense micelles consistent with the conductivity data. Further analyses using techniques such as small-angle neutron scattering may be necessary to identify the structure of the aggregates. ${ }^{24}$

The biological activity of complex $\mathbf{6}$ against the parasitic tapeworm, Hymenolepis diminuta, was of particular interest because previous studies had shown the surfactant cage complexes to be lethal to this parasite both in vitro and in vivo. ${ }^{1}$ The results of a simple incubation experiment demonstrated the lethal activity of $\mathbf{6}$ against the tapeworm at millimolar concentrations in vitro. At these concentrations, the complex causes severe physical damage to the tapeworm resulting in partial disintegration of the outer coat (tegument) of the worm within minutes. This layer is rich in lipids and, presumably, the lipophilic chain of the surfactant complex penetrates and introduces a large and highly charged cation into the membrane which destabilizes the double-layer. The cage head-group is also much larger and has a high positive charge relative to the singly negatively charged anionic head-groups of the membrane lipids. These factors probably account for the disruption observed in the membranes of cestodes and erythrocytes treated with these complexes. The redox-activity of the cobalt(III) cage head-group is not likely to be important in this context because it is a poor oxidant $\left\{E^{0} c a .-0.5 \mathrm{~V}\right.$ (vs. standard hydrogen electrode) $\}$.

The electrochemistry of the cobalt(III) surfactant cage complexes is similar to that of other cobalt sarcophagine-type cage complexes which undergo reversible reduction to the corresponding cobalt(II) cage complexes at potentials that are sensitive to the nature of the cage ligand substituents. This latter feature of cage redox chemistry can be used to modulate metal centred reduction potentials over a range of $c a$. $0.6 \mathrm{~V}$ with cobalt complexes of this type. ${ }^{4}$ The potential window could also be widened to at least $2 \mathrm{~V}$ by modulations in the cage ligand framework and by changing the encapsulated transition metal ion. ${ }^{21}$ Furthermore, the shift in potential correlates quantitatively with electrochemical polar substituent constants, which should allow surfactant complexes to be designed with specific redox potentials. ${ }^{17}$ The rate of outer-sphere electron transfer to or from the cage head-group is also amenable to systematic modulation over a range of $>10^{8}$ based on the established reactivity of various cage complexes with different combinations of encapsulated metal-ions and cage ligands. ${ }^{2,3}$ A class of surfactants with these types of redox properties is expected to yield new possibilities, for example, in the design of precisely controlled redox-switched self-assembly processes ${ }^{25,26}$ and for the study of electron transfer reactions at interfaces. ${ }^{27,28}$

\section{Experimental}

\section{Precursor complexes and reagents}

Racemic $[\mathrm{Co}(\mathrm{sen})] \mathrm{Cl}_{3}$ was prepared, ${ }^{29}$ and resolved on Sephadex cation-exchange resin with an aqueous eluent containing di-sodium bis-( $\mu$ - $d$-tartrato)-diantimonate(III) $\left\{\mathrm{Na}_{2}\left[\mathrm{Sb}_{2}-\right.\right.$ $\left.\left.\left((+)_{\mathrm{D}^{-}} \text {-tart }\right)_{2}\right]\right\}$ (see later). ${ }^{30}$ The di-methyl substituted cage com-

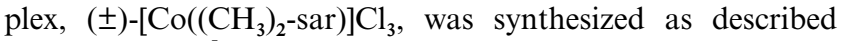
by Höhn et al. $^{5}$ Reported methods were used to prepare the surface-active cage complexes $\mathbf{2}$ and $\mathbf{3},{ }^{1}$ and $\left[\mathrm{Co}(\mathrm{sar}) \mathrm{Cl}_{3}{ }^{31}\right.$ Commercial 1-octadecanol was oxidized to octadecanal with an oxoammonium salt generated under phase transfer conditions. ${ }^{32}$ The organic reagents, paraformaldehyde (May \& Baker, 96\%), propanal (Aldrich, 97\%), decanal (98\%, Chemical Samples Co.), tetradecanal (Technical grade, Aldrich), and triethylamine (Aldrich) were all used as supplied. Triflic acid $\left(\mathrm{CF}_{3} \mathrm{SO}_{3} \mathrm{H}\right)$ obtained from the Aldrich Chemical Co. was redistilled under reduced pressure prior to use. All template reactions were carried out in stirred acetonitrile at $\sim 20^{\circ} \mathrm{C}$ with triethylamine as catalyst. Cobalt analyses of alkyl-substituted cobalt(III) cage complexes were obtained by atomic absorption spectrometry (AAS) after digestion of the complexes with concentrated $\mathrm{HNO}_{3}$ in an autoclave. The special sample preparation procedure was necessary to obtain consistent cobalt analyses from the surface-active cobalt cage complexes.

Analytical grade inorganic salts, acids and organic solvents were used to prepare reaction media, eluents, electrolyte solutions, buffers and metal-complexes.

\section{Chromatography}

Amphiphilic cobalt(III) cage complexes were isolated by column chromatography on silica gel (Silica Gel 60, 230-400 mesh, Merck). The unsaturated amphiphilic cobalt(III) cage complexes were eluted with a saturated solution of $\mathrm{NH}_{4} \mathrm{Cl}$ in $\mathrm{CH}_{3} \mathrm{OH}$, whereas the corresponding saturated cage complexes were eluted with a mixture of $\mathrm{CH}_{3} \mathrm{OH}$ in $\mathrm{CH}_{2} \mathrm{Cl}_{2}$. The nonlipophilic cobalt complexes were separated by aqueous column chromatography on Dowex AG 50W-X2 (BioRad, 200-400 mesh) and SP-Sephadex C-25 (Pharmacia) cation-exchange resins. Solutions in general were concentrated to dryness with a Büchi rotary-evaporator at reduced pressures ( $c a$. 15 Torr) and a bath temperature of $\sim 40{ }^{\circ} \mathrm{C}$. Aqueous solutions of the surface-active cage complexes were prone to sudden vigorous 'bumping' during rotary evaporation and due care was required.

\section{Spectroscopy}

A Varian Instruments Gemini 300 NMR spectrometer was used to acquire $300 \mathrm{MHz}{ }^{1} \mathrm{H} \mathrm{NMR}$ and $75.46 \mathrm{MHz}\left({ }^{1} \mathrm{H}\right.$-decoupled) ${ }^{13} \mathrm{C}$ NMR spectra. ADEPT spectra were acquired with a Varian Instruments VXR-300 spectrometer. All spectra of samples in $\mathrm{D}_{2} \mathrm{O}$ were referenced to internal 1,4-dioxane: $\delta_{\mathrm{H}}$ (1,4-dioxane in $\left.\mathrm{D}_{2} \mathrm{O}\right)=3.74 \mathrm{ppm} ; \delta_{\mathrm{C}}\left(1,4\right.$-dioxane in $\left.\mathrm{D}_{2} \mathrm{O}\right)=67.4 \mathrm{ppm}$. Spectra of samples in $\mathrm{CDCl}_{3}$ solution were referenced to internal TMS or the solvent. The assignment of spectra, particularly ${ }^{13} \mathrm{C}$ NMR spectra, was facilitated by the presence of a 3-fold symmetry axis in the saturated cations. In a few instances, signals 
could not be assigned unambiguously by reference to model compounds. The assignment of such resonances was generally based on NOE-enhanced ${ }^{1} \mathrm{H}$-coupled ${ }^{13} \mathrm{C}$ NMR spectra or ADEPT spectra.

Optical rotatory dispersion (ORD) spectra of solutions were acquired with a Perkin-Elmer model P22 recording spectropolarimeter using $1 \mathrm{dm}$ quartz cells maintained at $25.0 \pm$ $0.4{ }^{\circ} \mathrm{C}$. The concentration of the chiral cobalt complex in the test solution was $1.0 \times 10^{-3} \mathrm{~mol} \mathrm{dm}^{-3}$ unless otherwise indicated. Circular-dichroism spectra were acquired with a locally modified Cary model $61 \mathrm{CD}$ spectrometer, using $1.0 \times 10^{-3} \mathrm{~mol}$ $\mathrm{dm}^{-3}$ aqueous solutions in 2 and $5 \mathrm{~cm}$ path length quartz cells depending on the absorbance of the sample. The circular dichroism of $2-\left[\Lambda-(+)_{\mathrm{D}}-\left[\mathrm{Co}(\mathrm{en})_{3}\right] \mathrm{Cl}_{3}\right] \mathrm{NaCl} \cdot 6 \mathrm{H}_{2} \mathrm{O}{ }^{33}$ (en = 1,2ethanediamine) ion in aqueous solution was used to calibrate the CD instrument: $\Delta \varepsilon_{493}\left(\Lambda-(+)_{D^{-}}\left[\mathrm{Co}(\mathrm{en})_{3}\right]^{3+}\right)=+1.89 \mathrm{dm}^{3}$ $\mathrm{mol}^{-1} \mathrm{~cm}^{-1}{ }^{11}$

Ultraviolet and visible absorption spectra were acquired with a Hewlett-Packard HP8450A diode-array spectrophotometer or a Varian Instruments Cary $118 \mathrm{UV}$-vis spectrophotometer at $\sim 20^{\circ} \mathrm{C}$.

\section{Conductivity measurements}

Stock solutions of complex 6 were prepared in deionized $\mathrm{H}_{2} \mathrm{O}$ obtained from a Milli-Q filtering system $\left(\kappa\left(\mathrm{H}_{2} \mathrm{O}\right)=1.11 \times 10^{-6}\right.$ $\mathrm{S} \mathrm{cm}^{-1}$ ). Further test solutions were prepared by dilution from these stocks with deionized $\mathrm{H}_{2} \mathrm{O}$. Their conductivity was determined with a Radiometer CDM80 conductivity meter and CDC104 platinum conductivity probe. The conductivity cell constant $\left(0.984 \pm 0.002 \mathrm{~cm}^{-1}\right.$ at $\left.25.00{ }^{\circ} \mathrm{C}\right)$ was determined by comparison of the measured and reported conductivities of $1.0 \times 10^{-3} \mathrm{~mol} \mathrm{dm}^{-3}$ and $10 \times 10^{-3} \mathrm{~mol} \mathrm{dm}^{-3}$ aqueous $\mathrm{KCl}$ solutions. ${ }^{34}$ Test solutions in a glass tube were immersed in a constant temperature bath filled with kerosene (volume $\sim 12 \mathrm{~L}$ ) which was maintained at $T=25.00 \pm 0.02{ }^{\circ} \mathrm{C}$. The conductance was recorded after it remained constant with time $(\sim 10 \mathrm{~min})$.

\section{Biological methods}

The in vitro anthelmintic properties of complex 6 were examined using the rat tapeworm, Hymenolepis diminuta. The cestodes were extracted from the host rat and incubated in a nutrient buffer solution prior to treatment with the cage complex. An aqueous solution of $\mathbf{6}$ was added to the nutrient solution containing the worm until the final concentration of the complex was $\sim 10^{-3} \mathrm{~mol} \mathrm{dm}^{-3}$. The progress of the treatment was recorded photographically at selected intervals after administration of the surfactant.

The haemolytic activity of complex 6 was examined using erythrocytes in whole blood samples taken from an adult sheep. Test samples were prepared by mixing $10 \mu \mathrm{L}$ of blood, $90 \mu \mathrm{L}$ of a $0.15 \mathrm{~mol} \mathrm{dm}^{-3}$ aqueous $\mathrm{NaCl}$ solution and $10-50 \mu \mathrm{L}$ of a $5 \times 10^{-4} \mathrm{~mol} \mathrm{dm}^{-3}$ aqueous solution of 6 in an Eppendorf tube. The samples were viewed, after sealing a fraction of the mixture under a coverslip mounted on a glass microscope slide, with a Nikon light-microscope approximately 5-10 min after mixing the complex and the blood.

Tritrichomonas foetus (strain KV1) was cultured and harvested at the mid-log phase of the growth curve. ${ }^{35}$ Parasites were suspended at a density of $0.5 \times 10^{6}$ cells $\mathrm{mL}^{-1}$ in sterile phosphate-buffered saline $(137 \mathrm{mM} \mathrm{NaCl}, 2.69 \mathrm{mM} \mathrm{KCl}$, $10 \mathrm{mM} \mathrm{Na} \mathrm{HPO}_{4}, 1.8 \mathrm{mM} \mathrm{KH} \mathrm{PO}_{4}, \mathrm{pH}$ 7.2) supplemented with $50 \mathrm{mM}$ glucose. Aliquots $(200 \mu \mathrm{L})$ of the suspension in a 96-well microlitre plate were treated with the appropriate quantity of test compound dissolved in phosphate-buffered saline. The parasites were incubated under an air atmosphere at $37{ }^{\circ} \mathrm{C}$ for up to $24 \mathrm{~h}$ and their activity observed and scored at regular intervals using an inverted microscope. Each test was performed in duplicate.

\section{Electrochemistry}

Cyclic voltammograms of complexes in aqueous solution were acquired with a three-electrode cell connected to a BAS-100 electrochemical analyzer. The cell consisted of (i) a $3 \mathrm{~mm}$ diameter glassy carbon working electrode, (ii) a platinum wire auxiliary electrode and (iii) a saturated calomel reference electrode (SCE). A $0.2 \mathrm{~mol} \mathrm{dm}^{-3} \mathrm{KCl}$ salt bridge fitted with a Vycor frit separated the reference electrode from the test solution. Cyclic voltammograms of the complexes were recorded under a $\mathrm{H}_{2} \mathrm{O}$ saturated $\mathrm{N}_{2}$ atmosphere at $25.0 \pm 0.5^{\circ} \mathrm{C}$. Test solutions of the complexes were prepared with $0.2 \mathrm{~mol} \mathrm{dm}^{-3} \mathrm{NaCl}$ supporting electrolyte. The electrochemistry of solutions of the $\mathrm{C}_{12}$-cage complex $\mathbf{6}$ was investigated shortly after preparing the test solutions since the complex precipitated from this medium after several hours. The surface-active cage complexes were slow to dissolve in aqueous electrolyte solutions and generally these solutions were prepared by addition of $\mathrm{NaCl}$ to a solution of the cobalt(III) complex in $\mathrm{H}_{2} \mathrm{O}$. The $\mathrm{C}_{16}$-cage complex 7 was only sparingly soluble in $\mathrm{H}_{2} \mathrm{O}$ and insoluble in the aqueous electrolyte solution and was therefore excluded from this analysis.

\section{Synthesis}

$\left(4,4^{\prime}, 4^{\prime \prime}\right.$-Ethylidynetris(3-azabutan-1-amine))cobalt(III) triflate monohydrate, $( \pm)$-[Co(sen) $]\left(\mathrm{CF}_{3} \mathrm{SO}_{3}\right)_{3} \cdot \mathrm{H}_{2} \mathrm{O} 4$. A solution of $( \pm)$ $[\mathrm{Co}(\mathrm{sen})] \mathrm{Cl}_{3} \cdot \mathrm{H}_{2} \mathrm{O}{ }^{29}(9.2 \mathrm{~g}, 21.4 \mathrm{mmol})$ in neat $\mathrm{CF}_{3} \mathrm{SO}_{3} \mathrm{H}(20$ $\mathrm{cm}^{3}, 226 \mathrm{mmol}$ ) was purged with a stream of dry $\mathrm{N}_{2}$ to remove $\mathrm{HCl}$ evolved from the metathesis reaction. On dilution with $\mathrm{H}_{2} \mathrm{O}\left(500 \mathrm{~cm}^{3}\right)$, an orange crystalline precipitate formed which was recrystallized from a minimum volume of hot $\mathrm{H}_{2} \mathrm{O}$. Large orange needles of the triflate salt obtained upon cooling were collected and washed with a little ether. Concentration of the filtrates and cooling overnight afforded a further crop of the triflate salt which was isolated and washed with a little ether. Total yield $16 \mathrm{~g}, 97 \%$. Found: C, 21.7; H, 4.1; N, 10.9; F, 22.4; S, 12.0. $\mathrm{C}_{14} \mathrm{H}_{32} \mathrm{~N}_{6} \mathrm{CoF}_{9} \mathrm{O}_{10} \mathrm{~S}_{3}$ requires $\mathrm{C}, 21.8 ; \mathrm{H}, 4.2 ; \mathrm{N}, 10.9 ; \mathrm{F}$, $22.2 ; \mathrm{S}, 12.5 \%$. $\delta_{\mathrm{H}}\left(300 \mathrm{MHz}\right.$; solvent $\mathrm{D}_{2} \mathrm{O}$; reference $1,4-$ dioxane) $3.22\left(3 \mathrm{H}, \mathrm{m}, \mathrm{CH}_{2}\right), 3.01\left(6 \mathrm{H}, \mathrm{d}, \mathrm{CH}_{2}\right), 2.67(6 \mathrm{H}, \mathrm{m}$, $\left.\mathrm{CH}_{2}\right), 2.44\left(3 \mathrm{H}, \mathrm{d}, \mathrm{CH}_{2}\right)$ and $0.94\left(3 \mathrm{H}\right.$, s, cap- $\left.\mathrm{CH}_{3}\right) ; \delta_{\mathrm{C}}(75.46$ $\mathrm{MHz}$; solvent $\mathrm{D}_{2} \mathrm{O}$; reference 1,4-dioxane) 57.2, 55.4, 43.6 $\left(\mathrm{CH}_{2}\right)$ and $20.3\left(\mathrm{CH}_{3}\right)$. The $\mathrm{H}_{2} \mathrm{O}$ content of this product varied between 1-3 $\mathrm{H}_{2} \mathrm{O}$ molecules per complex for successive syntheses.

Resolution of $( \pm)-[\mathrm{Co}(\mathrm{sen})] \mathrm{Cl}_{3}$. A solution of $( \pm)$ $[\mathrm{Co}(\mathrm{sen})] \mathrm{Cl}_{3} \cdot \mathrm{H}_{2} \mathrm{O}$ in $\mathrm{H}_{2} \mathrm{O}\left(10 \mathrm{~g}(23 \mathrm{mmol})\right.$ in $\left.2 \mathrm{dm}^{3}\right)$ was absorbed on SP Sephadex C-25 cation exchange resin $(10 \times 92$ $\mathrm{cm}, \mathrm{Na}^{+}$form) in a thin orange band and washed with $\mathrm{H}_{2} \mathrm{O}$. The enantiomers were eluted with $0.1 \mathrm{~mol} \mathrm{dm}{ }^{-3} \mathrm{Na}_{2}\left[\mathrm{Sb}_{2}\left((+)_{\mathrm{D}^{-}}\right.\right.$ $\operatorname{tart})_{2}$ ]. Two well-separated bands of equal size were obtained by the time the leading fraction (I) reached the mid-point of the column. The leading band was collected and elution of the trailing fraction (II) was completed with $0.1 \mathrm{~mol} \mathrm{dm}{ }^{-3} \mathrm{~K}_{2} \mathrm{SO}_{4}$. The two fractions were separately absorbed on Dowex cationexchange resin $\left(6 \times 20 \mathrm{~cm}, \mathrm{Na}^{+}\right.$form $)$, washed with $\mathrm{H}_{2} \mathrm{O}$ and $1 \mathrm{~mol} \mathrm{dm}^{-3} \mathrm{HCl}$, and eluted with $3 \mathrm{~mol} \mathrm{dm}^{-3} \mathrm{HCl}$. The orange eluates, concentrated to a small volume and diluted with ethanol $\left(500 \mathrm{~cm}^{3}\right)$ deposited orange crystals after cooling overnight. These were filtered, washed with ethanol and ether, and air-dried. A second crop of crystals was obtained from the filtrates of each fraction. The leading fraction (I) $\left\{\Lambda-(-)_{\mathrm{D}^{-}}\right.$ $\left.[\mathrm{Co}(\mathrm{sen})] \mathrm{Cl}_{3} \cdot 3 \mathrm{H}_{2} \mathrm{O}\right\}$ combined yield $5.0 \mathrm{~g}, 93 \%$. ORD $\lambda / \mathrm{nm}$ $\left(\mathrm{H}_{2} \mathrm{O}\right) 477\left([\mathrm{M}] / \mathrm{deg} \mathrm{M} \mathrm{M}^{-1} \mathrm{~m}^{-1}-3675 \pm 40\right)$ and $423(+1498 \pm$ 20). Found: $\mathrm{C}, 28.7 ; \mathrm{H}, 7.8 ; \mathrm{N}, 18.1 . \mathrm{C}_{11} \mathrm{H}_{36} \mathrm{~N}_{6} \mathrm{Cl}_{3} \mathrm{CoO}_{3}$ requires C, 28.4; H, 7.8; N, 18.1\%. Trailing fraction (II) $\left(\Delta-(+)_{\mathrm{D}^{-}}\right.$ $\left.[\mathrm{Co}(\mathrm{sen})] \mathrm{Cl}_{3} \cdot 3 \mathrm{H}_{2} \mathrm{O}\right)$ combined yield $4.5 \mathrm{~g}, 84 \%$. ORD $\lambda / \mathrm{nm}$ $\left(\mathrm{H}_{2} \mathrm{O}\right) 477\left([\mathrm{M}] / \mathrm{deg} \mathrm{M} \mathrm{M}^{-1} \mathrm{~m}^{-1}+3736 \pm 40\right)$ and $423(-1528 \pm$ 20). Found: $\mathrm{C}, 28.2 ; \mathrm{H}, 7.6 ; \mathrm{N}, 17.7 . \mathrm{C}_{11} \mathrm{H}_{36} \mathrm{~N}_{6} \mathrm{Cl}_{3} \mathrm{CoO}_{3}$ requires C, $28.4 ; \mathrm{H}, 7.8 ; \mathrm{N}, 18.1 \%$. 


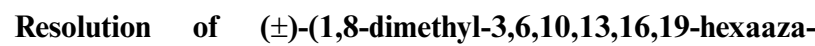
bicyclo[6.6.6]icosane) cobalt(III) chloride, $( \pm)-\left[\mathrm{Co}\left(\left(\mathrm{CH}_{3}\right)_{2}-\right.\right.$ sar) $] \mathrm{Cl}_{3}$. A similar procedure was used to resolve $( \pm)-[\mathrm{Co}-$ $\left(\left(\mathrm{CH}_{3}\right)_{2}\right.$-sar) $] \mathrm{Cl}_{3} \cdot \mathrm{H}_{2} \mathrm{O}^{5}(0.3 \mathrm{~g}, 0.61 \mathrm{mmol})$ on a column of Sephadex cation-exchange resin $(5.5 \times 29 \mathrm{~cm})$. The separated enantiomers were crystallised as tri-chloride salts from a minimum volume of hot $1 \mathrm{~mol} \mathrm{dm}^{-3} \mathrm{HCl}$ by the addition of acetone. Fraction (I) $\left(\Lambda-(-)_{\mathrm{D}^{-}}\left[\mathrm{Co}\left(\left(\mathrm{CH}_{3}\right)_{2}\right.\right.\right.$-sar $\left.\left.)\right] \mathrm{Cl}_{3} \cdot 3.5 \mathrm{H}_{2} \mathrm{O}\right)$ yield $0.117 \mathrm{~g}, 71 \%$. ORD $\lambda / \mathrm{nm}\left(\mathrm{H}_{2} \mathrm{O}\right) 504\left([\mathrm{M}] / \mathrm{deg} \mathrm{M}^{-1} \mathrm{~m}^{-1}-6098 \pm\right.$ $60)$ and $433(+7898 \pm 80) ; \mathrm{CD} \lambda / \mathrm{nm}\left(\mathrm{H}_{2} \mathrm{O}\right) 468\left(\Delta \varepsilon / \mathrm{dm}^{3} \mathrm{~mol}^{-1}\right.$ $\left.\mathrm{cm}^{-1}-3.27 \pm 0.03\right)$. Found: $\mathrm{C}, 35.4 ; \mathrm{H}, 7.7 ; \mathrm{N}, 15.4 . \mathrm{C}_{16} \mathrm{H}_{43} \mathrm{~N}_{6}$ $\mathrm{Cl}_{3} \mathrm{CoO}_{3.5}$ requires $\mathrm{C}, 35.5 ; \mathrm{H}, 8.0 ; \mathrm{N}, 15.5 \%$. Fraction (II) $\left(\Delta-(+)_{\mathrm{D}}-\left[\mathrm{Co}\left(\left(\mathrm{CH}_{3}\right)_{2}-\mathrm{sar}\right)\right] \mathrm{Cl}_{3} \cdot 5 \mathrm{H}_{2} \mathrm{O}\right)$ yield $0.112 \mathrm{~g}, 65 \%$. ORD $\lambda /$ $\mathrm{nm}\left(\mathrm{H}_{2} \mathrm{O}\right) 504\left([M] / \mathrm{deg} \mathrm{M}^{-1} \mathrm{~m}^{-1}+6149 \pm 60\right)$ and $433(-8049$ $\pm 80) ; \mathrm{CD} \lambda / \mathrm{nm}\left(\mathrm{H}_{2} \mathrm{O}\right) 468\left(\Delta \varepsilon / \mathrm{dm}^{3} \mathrm{~mol}^{-1} \mathrm{~cm}^{-1}+3.25 \pm 0.03\right)$ Found: $\mathrm{C}, 33.8 ; \mathrm{H}, 7.5 ; \mathrm{N}, 14.5 . \mathrm{C}_{16} \mathrm{H}_{46} \mathrm{~N}_{6} \mathrm{Cl}_{3} \mathrm{CoO}_{5}$ requires $\mathrm{C}$, $33.8 ; \mathrm{H}, 8.2 ; \mathrm{N}, 14.8 \%$.

\section{$(-)_{\mathrm{D}}-(1,8$-Dimethyl-3,6,10,13,16,19-hexaazabicyclo[6.6.6]-} icosane)cobalt(III) chloride trihydrate, $(-)_{\mathrm{D}}-\left[\mathrm{Co}\left(\left(\mathrm{CH}_{3}\right)_{2}\right.\right.$-sar $\left.)\right]-$ $\mathrm{Cl}_{3} \cdot 3 \mathrm{H}_{2} \mathrm{O}$ 8. Optically pure $\Lambda-(-)_{\mathrm{D}^{-}}[\mathrm{Co}(\operatorname{sen})] \mathrm{Cl}_{3} \cdot 3 \mathrm{H}_{2} \mathrm{O}(1.05 \mathrm{~g}$, $2.3 \mathrm{mmol}$ ), mostly dissolved in a solution of $\mathrm{NaClO}_{4} \cdot \mathrm{H}_{2} \mathrm{O}$ $(5.14 \mathrm{~g}, 36.7 \mathrm{mmol})$ in $\mathrm{CH}_{3} \mathrm{CN}\left(30 \mathrm{~cm}^{3}\right)$ was treated with paraformaldehyde $(0.169 \mathrm{~g}, 5.6 \mathrm{mmol})$ and propanal $(0.403 \mathrm{~g}$, $6.94 \mathrm{mmol})$. The condensation of the aldehydes with the complex was initiated with triethylamine $(0.690 \mathrm{~g}, 6.8 \mathrm{mmol})$ which resulted in a rapid color change of the mixture from orange to brown. The reaction mixture was stirred for $1.5 \mathrm{~h}$ at $\sim 21^{\circ} \mathrm{C}$ then quenched with glacial acetic acid $\left(5 \mathrm{~cm}^{3}\right)$. The orange mixture was diluted with $\mathrm{H}_{2} \mathrm{O}\left(500 \mathrm{~cm}^{3}\right)$ and absorbed on Dowex resin $\left(4 \times 15 \mathrm{~cm}, \mathrm{H}^{+}\right.$form $)$. A single orange band was eluted with $3 \mathrm{~mol} \mathrm{dm}{ }^{-3} \mathrm{HCl}$ after the column had been washed with water and $1 \mathrm{~mol} \mathrm{dm}^{-3} \mathrm{HCl}$ to remove some unsymmetrical byproduct complexes. The $3 \mathrm{~mol} \mathrm{dm}^{-3} \mathrm{HCl}$ fraction was taken to dryness and the solid residue obtained was dissolved in an aqueous solution of $\mathrm{NaHCO}_{3}\left(7.0 \mathrm{~g}\right.$ in $200 \mathrm{~cm}^{3}$ of $\left.\mathrm{H}_{2} \mathrm{O}\right)$ and treated with $\mathrm{NaBH}_{4}(0.085 \mathrm{~g}, 2.3 \mathrm{mmol})$. The reduction was

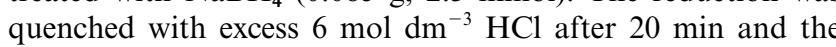
solution loaded onto Dowex resin $\left(4 \times 7.5 \mathrm{~cm}, \mathrm{H}^{+}\right.$form $)$. The sorbed complexes were washed with $\mathrm{H}_{2} \mathrm{O}$ and $1 \mathrm{~mol} \mathrm{dm}^{-3} \mathrm{HCl}$, and then eluted with $3 \mathrm{~mol} \mathrm{dm}^{-3} \mathrm{HCl}$. After evaporation, the residue was dissolved in $\mathrm{H}_{2} \mathrm{O}$ and loaded on Sephadex resin $\left(5.5 \times 25 \mathrm{~cm}, \mathrm{Na}^{+}\right.$form $)$. The sorbed complexes were washed with $\mathrm{H}_{2} \mathrm{O}$ and eluted with $0.1 \mathrm{~mol} \mathrm{dm}^{-3}$ tri-sodium citrate. The desired product eluted first as the major orange fraction followed by some minor pink, orange and brown bands, which were discarded. The major orange fraction was desalted on Dowex as described above and crystallized from a minimum volume of hot $\mathrm{H}_{2} \mathrm{O}$ by the addition of acetone and ether. The product was collected, washed with ether, and air-dried. Yield $0.56 \mathrm{~g}, 46 \%$. ORD $\lambda / \mathrm{nm}\left(\mathrm{H}_{2} \mathrm{O}\right) 505\left([M] / \mathrm{deg} \mathrm{M}^{-1} \mathrm{~m}^{-1}-5419\right)$ and 434 (+6974). Found: C, 36.1; H, 8.2; N, 15.8. $\mathrm{C}_{16} \mathrm{H}_{42} \mathrm{~N}_{6}$ $\mathrm{Cl}_{3} \mathrm{CoO}_{3}$ requires $\mathrm{C}, 36.1 ; \mathrm{H}, 8.0 ; \mathrm{N}, 15.8 \%$. The ${ }^{1} \mathrm{H}$ and ${ }^{13} \mathrm{C}$ NMR spectra of this complex in $\mathrm{D}_{2} \mathrm{O}$ were identical to the spectra for the racemic complex. ${ }^{5}$

( \pm )-(1-Methyl-8-octyl-3,6,10,13,16,19-hexaazabicyclo[6.6.6]icosane) cobalt(III) chloride monohydrate 5. Paraformaldehyde $(0.293 \mathrm{~g}, 9.8 \mathrm{mmol})$ and decanal $(1.21 \mathrm{~g}, 7.8 \mathrm{mmol})$ were added to a stirred orange solution of $( \pm)-[\mathrm{Co}(\mathrm{sen})]\left(\mathrm{CF}_{3} \mathrm{SO}_{3}\right)_{3} \cdot \mathrm{H}_{2} \mathrm{O}$ ( $3 \mathrm{~g}, 3.9 \mathrm{mmol})$ in $\mathrm{CH}_{3} \mathrm{CN}\left(90 \mathrm{~cm}^{3}\right)$. The encapsulation reaction was initiated by addition of triethylamine $\left(0.79 \mathrm{~g}\right.$ in $4 \mathrm{~cm}^{3}$ $\mathrm{CH}_{3} \mathrm{CN}, 7.8 \mathrm{mmol}$ ), which resulted in a rapid darkening of the reaction mixture from orange to brown-orange. After quenching with glacial acetic acid $\left(10 \mathrm{~cm}^{3}\right)$ following stirring for $2 \mathrm{~h}$ at $\sim 20^{\circ} \mathrm{C}$, the mixture was evaporated to a viscous brown-orange oil, then redissolved in $\mathrm{CHCl}_{3}$ and a minimum volume of $\mathrm{CH}_{3} \mathrm{OH}$. The solution was loaded on a column of silica gel $\left(5 \times 10 \mathrm{~cm}, \mathrm{CHCl}_{3}\right)$ and washed with $\mathrm{CHCl}_{3}$ to remove some minor brown compounds. A dark brown band and a larger orange fraction containing the desired product were then eluted with $10 \% \mathrm{CH}_{3} \mathrm{OH}$ in $\mathrm{CHCl}_{3}$ followed by saturated $\mathrm{NH}_{4} \mathrm{Cl}$ in $\mathrm{CH}_{3} \mathrm{OH}$; some minor gray and pink compounds remained on the column under these conditions and were later discarded. The tail of the brown band and the entire orange fraction were collected, combined, and taken to dryness. The complex was dissolved in $\mathrm{CH}_{2} \mathrm{Cl}_{2}$ and filtered to remove the insoluble salts. After evaporation, the residue was dissolved in $\mathrm{CH}_{3} \mathrm{OH}$ $\left(100 \mathrm{~cm}^{3}\right)$ buffered with sodium tetraborate $(1.1 \mathrm{~g})$, and the imine cage complex reduced with $\mathrm{NaBH}_{4}(0.3 \mathrm{~g}, 7.9 \mathrm{mmol})$. The reduction reaction was quenched with excess $6 \mathrm{~mol} \mathrm{dm}^{-3} \mathrm{HCl}$ after $20 \mathrm{~min}$ and the mixture taken to dryness. The impure saturated cage complex was dissolved in $\mathrm{CH}_{2} \mathrm{Cl}_{2}$ and the solution filtered to remove insoluble salts. The filtrates were loaded on silica gel $\left(5 \times 15 \mathrm{~cm}, \mathrm{CH}_{2} \mathrm{Cl}_{2}\right)$ and the column washed with $\mathrm{CH}_{2} \mathrm{Cl}_{2}$ to remove some minor brown compounds. The desired orange product was removed with $20 \% \mathrm{CH}_{3} \mathrm{OH}$ in $\mathrm{CH}_{2} \mathrm{Cl}_{2}$; several minor green, red-orange and gray bands, which remained bound to the gel under these conditions, were discarded. After evaporation, the orange complex was dissolved in refluxing $\mathrm{CH}_{3} \mathrm{CN}$ and filtered. The filtrate was taken to dryness and the complex dissolved in $\mathrm{CH}_{3} \mathrm{OH}$. It was then precipitated from solution with ether, collected, and washed with ether. Yield 1.1 g, 48\%. Found: C, 46.9; H, 8.8; N, 14.0; Cl, 17.7; Co, 10.1. $\mathrm{C}_{23} \mathrm{H}_{52} \mathrm{~N}_{6} \mathrm{Cl}_{3} \mathrm{CoO}$ requires $\mathrm{C}, 46.5 ; \mathrm{H}, 8.8 ; \mathrm{N}, 14.2 ; \mathrm{Cl}$, 17.9; $\mathrm{Co}, 9.9 \%$. $\delta_{\mathrm{H}}\left(\mathrm{D}_{2} \mathrm{O}\right) 3.28\left(6 \mathrm{H}\right.$, dd, en- $\left.\mathrm{CH}_{2}\right), 3.06(6 \mathrm{H}, \mathrm{d}$, $J_{\mathrm{AB}}=13.7 \mathrm{~Hz}$, cap- $\left.\mathrm{CH}_{2}\right), 2.72\left(6 \mathrm{H}\right.$, dd, en- $\left.\mathrm{CH}_{2}\right), 2.44(6 \mathrm{H}, \mathrm{d}$, $J_{\mathrm{AB}}=13.7 \mathrm{~Hz}$, cap- $\left.\mathrm{CH}_{2}\right), 1.25\left(14 \mathrm{H}\right.$, br s, chain- $\left.\mathrm{CH}_{2}\right), 0.91$ $\left(3 \mathrm{H}, \mathrm{s}\right.$, cage- $\left.\mathrm{CH}_{3}\right)$ and $0.84\left(3 \mathrm{H}, \mathrm{t}\right.$, chain- $\left.\mathrm{CH}_{3}\right) ; \delta_{\mathrm{C}}\left(\mathrm{D}_{2} \mathrm{O}\right)$ 55.6, 55.5, 55.2, 54.3 (cage- $\mathrm{CH}_{2}$ ), 46.0, 42.9 (quat. C), 35.2, $32.3,30.5,29.6,23.1\left(\right.$ chain- $\left.\mathrm{CH}_{2}\right), 20.2\left(\right.$ cage- $\left.\mathrm{CH}_{3}\right)$ and 14.6 (chain- $\mathrm{CH}_{3}$ )

\section{( \pm )-(1-Methyl-8-dodecyl-3,6,10,13,16,19-hexaazabicyclo-} [6.6.6]icosane) cobalt(III) chloride dihydrate 6. A stirred solution of $( \pm)-[\mathrm{Co}(\mathrm{sen})]\left(\mathrm{CF}_{3} \mathrm{SO}_{3}\right)_{3} \cdot 2.5 \mathrm{H}_{2} \mathrm{O} \quad(10 \mathrm{~g}, 12.5 \mathrm{mmol})$ in $\mathrm{CH}_{3} \mathrm{CN}\left(300 \mathrm{~cm}^{3}\right)$ was treated with paraformaldehyde $(0.941 \mathrm{~g}$, $31 \mathrm{mmol})$ and tetradecanal ( $5 \mathrm{~g}, c a .24 \mathrm{mmol})$ to give a white suspension of the aldehydes in an orange solution of the template complex. The reaction was initiated by the addition of triethylamine (2.54 $\mathrm{g}$ in $\left.2.5 \mathrm{~cm}^{3} \mathrm{CH}_{3} \mathrm{CN}, 25 \mathrm{mmol}\right)$ which caused a rapid darkening of the reaction mixture from orange to brown-orange. The mixture was then quenched with glacial acetic acid $\left(10 \mathrm{~cm}^{3}\right)$ after $3 \mathrm{~h}$ at $\sim 20{ }^{\circ} \mathrm{C}$, filtered to remove an insoluble white precipitate and taken to dryness. The crude product was dissolved in $\mathrm{CH}_{3} \mathrm{OH} / \mathrm{CH}_{2} \mathrm{Cl}_{2}\left(1 / 10,110 \mathrm{~cm}^{3}\right)$, loaded on silica gel $\left(6 \times 13.5 \mathrm{~cm}, \mathrm{CH}_{2} \mathrm{Cl}_{2}\right)$, and the column washed with $\mathrm{CH}_{2} \mathrm{Cl}_{2}$. An orange fraction containing the desired product was eluted with $\mathrm{CH}_{3} \mathrm{OH}$ and then saturated $\mathrm{NH}_{4} \mathrm{Cl}$ in $\mathrm{CH}_{3} \mathrm{OH}$. After evaporation to dryness, the residue was dissolved in $\mathrm{CH}_{2} \mathrm{Cl}_{2}$, filtered and the filtrate evaporated to dryness again. Finally, the imine cage complex was dissolved in $\mathrm{CH}_{3} \mathrm{OH}$ $\left(100 \mathrm{~cm}^{3}\right)$ and treated with an excess of $\mathrm{NaBH}_{4}(0.574 \mathrm{~g}, 15.1$ $\mathrm{mmol}$ ) for $\sim 1 \mathrm{~h}$ at $\sim 21^{\circ} \mathrm{C}$. After evaporation, the impure saturated cage ligand complex was dissolved in $\mathrm{CH}_{2} \mathrm{Cl}_{2}$, filtered and loaded on silica gel $\left(6 \times 14 \mathrm{~cm}, \mathrm{CH}_{2} \mathrm{Cl}_{2}\right)$. Washing with $\mathrm{CH}_{2} \mathrm{Cl}_{2}$ removed a thin brown-orange band. The main orange band, containing the desired product, was eluted with $15 \% \mathrm{CH}_{3} \mathrm{OH}$ in $\mathrm{CH}_{2} \mathrm{Cl}_{2}$ and evaporated. After dissolution in a minimum of boiling $\mathrm{CH}_{3} \mathrm{CN}$, the filtrate was taken to dryness and the orange solid obtained was dissolved in a minimum volume of $\mathrm{CH}_{3} \mathrm{OH}$. A yellow-orange powder was precipitated by addition of ether to this solution. The solid product was isolated, washed with ether, and air-dried. Yield $5.0 \mathrm{~g}, 58 \%$. Found: C, 48.8; H, 9.6; N, 12.6; $\mathrm{Cl}, 15.6 ; \mathrm{Co}, 8.8 . \mathrm{C}_{27} \mathrm{H}_{62} \mathrm{~N}_{6} \mathrm{Cl}_{3} \mathrm{CoO}_{2}$ requires $\mathrm{C}, 48.5 ; \mathrm{H}$, 9.4; N, 12.6; Cl, 15.9; Co, 8.8\%. $\lambda_{\text {max }} / \mathrm{nm}_{\left(\mathrm{H}_{2} \mathrm{O}\right)} 470\left(\varepsilon / \mathrm{dm}^{3}\right.$ $\left.\mathrm{mol}^{-1} \mathrm{~cm}^{-1} 149 \pm 9\right)$ and $343(122 \pm 7) ; \delta_{\mathrm{H}}\left(\mathrm{D}_{2} \mathrm{O}\right) 3.30(6 \mathrm{H}, \mathrm{m}$, en- $\left.\mathrm{CH}_{2}\right), 3.08\left(6 \mathrm{H}, \mathrm{m}\right.$, cap- $\left.\mathrm{CH}_{2}\right), 2.80\left(6 \mathrm{H}, \mathrm{m}\right.$, en- $\left.\mathrm{CH}_{2}\right), 2.46$ $\left(6 \mathrm{H}, \mathrm{m}\right.$, cap- $\left.\mathrm{CH}_{2}\right), 1.25\left(22 \mathrm{H}\right.$, br s, chain- $\left.\mathrm{CH}_{2}\right), 0.94(3 \mathrm{H}, \mathrm{s}$, cage- $\left.\mathrm{CH}_{3}\right)$ and $0.84\left(3 \mathrm{H}\right.$, t, chain- $\left.\mathrm{CH}_{3}\right) ; \delta_{\mathrm{C}}\left(\mathrm{D}_{2} \mathrm{O}\right)$ 55.8, 55.7, 
55.1, 54.4 (cage- $\mathrm{CH}_{2}$ ), 46.1, 43.1 (quat. C), 35.6, 32.8, 31.3, $30.7,30.6,30.3,23.6,23.5$ (chain- $\left.\mathrm{CH}_{2}\right), 20.2\left(\right.$ cage- $\left.\mathrm{CH}_{3}\right)$ and 14.9 (chain- $\mathrm{CH}_{3}$ ). The complex was also obtained as a crystalline solid (orange needles) by the addition of chloride ions (from $\mathrm{HCl}, \mathrm{NaCl}$ or $\mathrm{LiCl}$ ) to an aqueous solution of the complex $\left(\sim 0.2 \mathrm{~mol} \mathrm{dm}^{-3}\right)$.

\section{$(-)_{\mathrm{D}}-(1-$-Methyl-8-dodecyl-3,6,10,13,16,19-hexaazabicyclo-}

[6.6.6]icosane) cobalt(III) chloride trihydrate $(-)_{\mathrm{D}}-(6)$. Optically pure $\Lambda-(-)_{\mathrm{D}}-[\mathrm{Co}(\mathrm{sen})] \mathrm{Cl}_{3} \cdot 3 \mathrm{H}_{2} \mathrm{O}(1.03 \mathrm{~g}, 2.2 \mathrm{mmol})$, mostly dissolved in a solution of $\mathrm{NaCF}_{3} \mathrm{SO}_{3}(3.0 \mathrm{~g}, 17.4 \mathrm{mmol})$ in $\mathrm{CH}_{3} \mathrm{CN}\left(30 \mathrm{~cm}^{3}\right)$, was treated with paraformaldehyde $(0.162 \mathrm{~g}$, $5.4 \mathrm{mmol})$ and tetradecanal $(0.914 \mathrm{~g}, 4.3 \mathrm{mmol})$ to give, initially, a white suspension of the aldehydes in a stirred orange solution of the template complex. The reaction, initiated by addition of triethylamine $(0.438 \mathrm{~g}, 4.33 \mathrm{mmol})$, was quenched with glacial acetic acid $\left(5 \mathrm{~cm}^{3}\right)$ after stirring for $3.5 \mathrm{~h}$ at $\sim 20^{\circ} \mathrm{C}$. The impure imine cage complex product was partially purified and then reduced as described above for the racemic $\mathrm{C}_{12}$-complex. The saturated cage ligand complex was dissolved in $\mathrm{H}_{2} \mathrm{O}$, absorbed on Dowex resin $\left(\mathrm{H}^{+}\right.$form, $\left.2 \times 8 \mathrm{~cm}\right)$, washed with $\mathrm{H}_{2} \mathrm{O}, 1 \mathrm{~mol}$ $\mathrm{dm}^{-3} \mathrm{HCl}$ and $3 \mathrm{~mol} \mathrm{dm}^{-3} \mathrm{HCl}$, and finally eluted with a $1: 1$ mixture of concentrated aqueous $\mathrm{HCl}$ and ethanol. The orange eluate was evaporated and a yellow-orange powder was obtained. Yield $0.60 \mathrm{~g}, 39 \%$. ORD $\lambda / \mathrm{nm}\left(\mathrm{H}_{2} \mathrm{O}\right) 505([\mathrm{M}] / \mathrm{deg}$ $\left.\mathrm{M}^{-1} \mathrm{~m}^{-1}-6000 \pm 70\right)$ and $434(+8920 \pm 90) ; \mathrm{CD} \lambda / \mathrm{nm}\left(\mathrm{H}_{2} \mathrm{O}\right)$ $468\left(\Delta \varepsilon / \mathrm{dm}^{3} \mathrm{~mol}^{-1} \mathrm{~cm}^{-1}-3.43\right)$. Found: $\mathrm{C}, 47.1 ; \mathrm{H}, 9.0 ; \mathrm{N}, 12.0$. $\mathrm{C}_{27} \mathrm{H}_{64} \mathrm{~N}_{6} \mathrm{Cl}_{3} \mathrm{CoO}_{3}$ requires $\mathrm{C}, 47.3 ; \mathrm{H}, 9.4 ; \mathrm{N}, 12.3 \%$. The ${ }^{1} \mathrm{H}$ and ${ }^{13} \mathrm{C}$ NMR spectra of this complex were identical to the spectra of the racemic $\mathrm{C}_{12}$-substituted cage complex.

( \pm )-(1-Methyl-8-hexadecyl-3,6,10,13,16,19-hexaazabicyclo[6.6.6]icosane) cobalt(III) chloride monohydrate 7. Paraformaldehyde (0.14 g, $4.7 \mathrm{mmol})$ and octadecanal (1.01 g, $3.8 \mathrm{mmol})$ were added to a stirred orange solution of $( \pm)-[\mathrm{Co}(\operatorname{sen})]-$ $\left(\mathrm{CF}_{3} \mathrm{SO}_{3}\right)_{3} \cdot 2.5 \mathrm{H}_{2} \mathrm{O}(1.492 \mathrm{~g}, 1.8 \mathrm{mmol})$ in $\mathrm{CH}_{3} \mathrm{CN}\left(45 \mathrm{~cm}^{3}\right)$ to give a clumpy white suspension. Triethylamine $\left(0.379 \mathrm{~g}\right.$ in $2 \mathrm{~cm}^{3}$ of $\mathrm{CH}_{3} \mathrm{CN}, 3.8 \mathrm{mmol}$ ) was added to the stirred suspension, which caused the reaction mixture to darken from orange to brown-orange. After $3 \mathrm{~h}$ at $\sim 20^{\circ} \mathrm{C}$, the reaction was quenched with glacial acetic acid $\left(5 \mathrm{~cm}^{3}\right)$. The quenched reaction mixture was filtered to remove a cream colored precipitate, filtered and the solid washed with $\mathrm{CH}_{3} \mathrm{CN}$ until the washings were colourless. The combined orange filtrates were loaded on silica gel $\left(6 \times 14 \mathrm{~cm}, \mathrm{CH}_{2} \mathrm{Cl}_{2}\right)$, the column washed with $\mathrm{CH}_{3} \mathrm{OH}$, and an orange product eluted with saturated $\mathrm{NH}_{4} \mathrm{Cl}$ in $\mathrm{CH}_{3} \mathrm{OH}$. The orange eluate was taken to dryness, the residue was dissolved in $\mathrm{CH}_{2} \mathrm{Cl}_{2}$, filtered and the filtrate evaporated to dryness again. The orange residue was dissolved in $\mathrm{CH}_{3} \mathrm{OH}\left(100 \mathrm{~cm}^{3}\right)$, and the imine complex reduced with $\mathrm{NaBH}_{4}(0.072 \mathrm{~g}, 1.9 \mathrm{mmol})$ over a $20 \mathrm{~min}$ period at $\sim 20^{\circ} \mathrm{C}$. Following quenching with excess $6 \mathrm{~mol}$ $\mathrm{dm}^{-3} \mathrm{HCl}$ and evaporation, the orange product was dissolved in a minimum volume of hot $\mathrm{H}_{2} \mathrm{O}$ and allowed to cool overnight. Fine orange crystals deposited. $\mathrm{HCl}$ was added to precipitate the remaining complex in solution. The combined products were dissolved in $\mathrm{CH}_{2} \mathrm{Cl}_{2}\left(200 \mathrm{~cm}^{3}\right)$ and the solution shaken with aqueous ethanol $\left(100 \mathrm{~cm}^{3}\right)$. The faintly coloured aqueous phase was removed and the organic phase washed with a further quantity of aqueous ethanol; this extraction procedure was necessary to fully purify the complex. The aqueous phases were discarded and the organic phase taken to dryness. The complex was crystallized from a minimum volume of hot $1 \mathrm{~mol} \mathrm{dm}^{-3}$ $\mathrm{HCl}$, filtered, washed with $6 \mathrm{~mol} \mathrm{dm}{ }^{-3} \mathrm{HCl}$, and dried over $\mathrm{P}_{2} \mathrm{O}_{5}$ (under a partial vacuum). Yield $0.58 \mathrm{~g}, 46 \%$. Found: $\mathrm{C}, 52.6 ; \mathrm{H}$, 11.0; N, 11.6; $\mathrm{Cl}, 14.8 ; \mathrm{Co}, 8.3 . \mathrm{C}_{31} \mathrm{H}_{68} \mathrm{~N}_{6} \mathrm{Cl}_{3} \mathrm{CoO}$ requires $\mathrm{C}$, 52.7; H, 9.7; N, 11.9; Cl, 15.1; Co, 8.3\%. $\delta_{\mathrm{H}}(300 \mathrm{MHz}$, solvent $\mathrm{CDCl}_{3}$, reference solvent) $8.93(6 \mathrm{H}$, br s, NH), $3.11(6 \mathrm{H}, \mathrm{br}$, cage- $\left.\mathrm{CH}_{2}\right), 2.93\left(12 \mathrm{H}, \mathrm{m}\right.$, cage- $\left.\mathrm{CH}_{2}\right), 2.12\left(6 \mathrm{H}\right.$, d, cap- $\left.\mathrm{CH}_{2}\right)$, $1.22\left(30 \mathrm{H}\right.$, br, chain- $\left.\mathrm{CH}_{2}\right), 0.89\left(3 \mathrm{H}\right.$, s, cage- $\left.\mathrm{CH}_{3}\right)$ and 0.84 $\left(3 \mathrm{H}, \mathrm{t}\right.$, chain- $\left.\mathrm{CH}_{3}\right) ; \delta_{\mathrm{C}}\left(75.46 \mathrm{MHz}\right.$, solvent $\mathrm{CDCl}_{3}$, reference solvent) 55.1, 53.8 (cage- $\mathrm{CH}_{2}$ ), 45.6, 42.7 (quat. C), 35.4, 31.8, 29.9, 29.6, 29.5, 29.3, 29.2, 23.0, 22.6 (chain- $\left.\mathrm{CH}_{2}\right), 20.8$ (cage- $\mathrm{CH}_{3}$ ) and 14.1 (chain- $\mathrm{CH}_{3}$ ).

\section{Acknowledgements}

We thank Professor Brian Gunning (Research School of Biological Sciences, ANU) and Ms Marilyn Karaman (Department of Chemistry, The Faculties, ANU) for their assistance with the erythrocyte experiments, $\mathrm{Dr}$ Sendaba Gerba (RSC, ANU) for the synthesis of octadecanal, ANU's Microanalytical Section and NMR Centre, and the Australian Institute of Nuclear Science and Engineering for the award of a post-graduate supplement (GWW).

\section{References}

1 C. A. Behm, P. F. L. Boreham, I. I. Creaser, B. KorybutDaszkiewicz, D. J. Maddalena, A. M. Sargeson and G. M. Snowdon, Aust. J. Chem., 1995, 48, 1009-1030.

2 I. I. Creaser, A. M. Sargeson and A. W. Zanella, Inorg. Chem., 1983, 22, 4022-4029.

3 P. Bernhard and A. M. Sargeson, Inorg. Chem., 1987, 26, 4122-4125.

4 A. M. Bond, G. A. Lawrance, P. A. Lay and A. M. Sargeson, Inorg. Chem., 1983, 22, 2010-2021.

5 A. Höhn, R. J. Geue and A. M. Sargeson, J. Chem. Soc., Chem. Commun., 1990, 1473-1475.

6 R. J. Geue, B. Korybut-Daszkiewicz and A. M. Sargeson, J. Chem. Soc., Chem. Commun., 1993, 1454-1456.

7 R. J. Geue, B. Korybut-Daszkiewicz and A. M. Sargeson, Chem. Commun., 1996, 1569-1570.

8 P. M. Angus, A. M. T. Bygott, R. J. Geue, B. Korybut-Daszkiewicz, A. W. H. Mau, A. M. Sargeson, M. M. Sheil and A. C. Willis, Chem. Eur. J., 1997, 3, 1283-1291.

9 A preliminary report of the synthesis and biological activity of these complexes has already appeared: see C. A. Behm, I. I. Creaser, B. Korybut-Daszkiewicz, R. J. Geue, A. M. Sargeson and G. W. Walker, J. Chem. Soc., Chem. Commun., 1993, 1844-1846.

10 A. E. Alexander and P. Johnson, Colloid Science, Oxford University Press, Oxford, 1950.

11 S. F. Mason, Q. Rev., Chem. Soc., 1963, 17, 20-66.

12 I. I. Creaser, R. J. Geue, J. M. Harrowfield, A. J. Herlt, A. M. Sargeson, M. R. Snow and J. Springborg, J. Am. Chem. Soc., 1982, 104, 6016-6025.

13 L. Dubicki, J. Ferguson, R. J. Geue and A. M. Sargeson, Chem. Phys. Lett., 1980, 74, 393-397.

14 B. M. Honigberg, in Parasitic Protozoa, ed. J. P. Kreier, Academic Press, New York, 1978, vol. II, pp. 163-258.

15 R. H. Wopschall and I. Shain, Anal. Chem., 1967, 39, 1514-1534

16 J. T. Hupp, H. Y. Liu, P. A. Lay, W. H. F. Petri, A. M. Sargeson and M. J. Weaver, J. Electroanal. Chem., 1984, 163, 371-379.

17 G. A. Lawrance, P. A. Lay and A. M. Sargeson, Inorg. Chem., 1990, 29, 4808-4816.

18 C. A. Grob, B. Schaub and M. G. Schlageter, Helv. Chim. Acta, $1980,63,57-62$.

19 A. Hammershøi and A. M. Sargeson, Inorg. Chem., 1983, 22, 3554 3561.

20 P. Osvath, A. M. Sargeson, A. McAuley, R. E. Mendelez, S. Subramanian, M. J. Zaworotko and L. Broge, Inorg. Chem., 1999, 38, 3634-3643

21 A. M. Sargeson, Pure Appl. Chem., 1984, 56, 1603-1619.

22 M. E. Karaman, R. M. Pashley and N. K. Bolonkin, Langmuir, 1995, 11, 2872-2880.

23 B. T. Ingram and R. H. Ottewill, in Surfactant Science Series, ed. D. N. Rubingh and P. M. Holland, Marcel Dekker, New York, 1991, vol. 37, pp. 87-140.

24 This technique was recently used to probe the shape and aggregation number of surface-active nickel(II) and copper(II) aza-macrocycle complexes in water. For details see: I. A. Fallis, P. C. Griffiths, P. M. Griffiths, D. E. Hibbs, M. B. Hursthouse and A. L. Winnington, Chem. Commun., 1998, 665-666.

25 T. Saji, K. Hoshino and S. Aoyagui, J. Am. Chem. Soc., 1985, 107, 6865-6868.

26 N. Aydogan, B. S. Gallardo and N. L. Abbott, Langmuir, 1999, 15, 722-730.

27 G. L. Gaines, Jr., Inorg. Chem., 1980, 19, 1710-1714.

28 F. M. el Torki, R. H. Schmehl and W. F. Reed, J. Chem. Soc., Faraday Trans. 1, 1989, 85, 349-362.

29 R. J. Geue and G. H. Searle, Aust. J. Chem., 1983, 36, 927-935. 
30 H. Okazaki, U. Sakaguchi and H. Yoneda, Inorg. Chem., 1983, 22, 1539-1542.

31 R. J. Geue, T. W. Hambley, J. M. Harrowfield, A. M. Sargeson and M. R. Snow, J. Am. Chem. Soc., 1984, 106, 5478-5488.

32 P. L. Anelli, C. Biffi, F. Montanari and S. Quici, J. Org. Chem., 1987, 52, 2559-2562.
33 K. Nakatsu, M. Shiro, Y. Saito and H. Kuroya, Bull. Chem. Soc. Jpn., 1957, 30, 158-164.

34 R. A. Robinson and R. H. Stokes, in Electrolyte Solutions, Butterworths, Bath, 1959.

35 M. Page-Sharp, C. A. Behm and G. D. Smith, Microbiology, 1996, 142, 207-211. 